\title{
On Fennoscandian polypores 9. Gelatoporia n.gen. and Tyromyces canadensis, plus notes on Skeletocutis and Antrodia
}

\author{
TUOMO NIEMELÄ
}

\begin{abstract}
NIEMELÄ, T. 1985: On Fennoscandian polypores 9. Gelatoporia n.gen. and Tyromyces canadensis, plus notes on Skeletocutis and Antrodia. - Karstenia 25: $21-40$.

A new genus, Gelatoporia Niemelä, is described, to embrace resupinate polypores with a monomitic structure, clamped hyphae and white-rot. G. pannocincta (Rom.) Niemelä, n.comb., is redescribed. G. subvermispora (Pilát) Niemelä, n.comb. (type of the genus), is reported as new to Fennoscandia. Tyromyces canadensis Overh. ex Lowe (Antrodiella overholtsii Ryv. \& Gilb.) is reported for the first time outside North America; its characteristics, taxonomy and nomenclature are discussed. Skeletocutis carneogrisea David is reported as new to Finland and provided with some ecological notes. Skeletocutis odora (Sacc.) Ginns is shown to be an older name for $S$. tschulymica (Pilát) Keller, Antrodia pulvinascens (Pilát) Niemelä, n.comb., for A. plicata Niemelä, and A. macra (Sommerf.) Niemelä, n.comb., for Trametes salicina Bres. (Antrodia salicina). Most species are illustrated by photographs and microscopic drawings. A new method of indicating microchemical reactions is proposed and the reliability of Cresyl Blue in the polypore taxonomy is reviewed.
\end{abstract}

Tuomo Niemelä, Department of Botany, University of Helsinki, Unioninkatu 44, SF00170 Helsinki, Finland

Introduction

Materials and methods

Gelatoporia Niemelä, n.gen.

Gelatoporia pannocincta (Romell) Niemelä, n.comb.

Identification

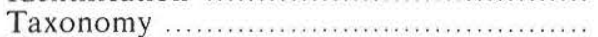

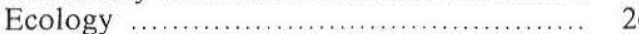

Distribution ................................. 28

Selected specimens examined ............... 28

Gelatoporia subvermispora (Pilát) Niemelä,

n.comb.

Identification

Ecology and distribution .................... 31

Specimens examined ......................... 32

Tyromyces canadensis Overh. ex Lowe ........... 32

Notes on the species ....................... 33

Nomenclatural notes ....................... 34

Specimens examined ........................ 35

Notes on Skeletocutis .......................... 35

Skeletocutis carneogrisea .................. 35

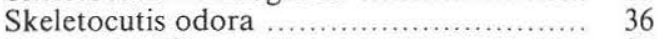

Notes on Antrodia ............................. 37

Antrodia pulvinascens (Pilát) Niemelä,

n.comb.

Antrodia macra (Sommerf.) Niemelä,

n.comb.

References

6

26

8

8

S
Skeletocutis Kotl. \& Pouz. remained a monotypic
Skelorid curiosity, until Keller (1979) discovered in it the characteristic encrusted hyphae earlier known only from Incrustoporia Dom. This led to the merging of Incrustoporia with Skeletocutis; later David (1982) and David \& Keller (1984) found many undescribed species in the group, and further additions were made by Ginns (1984) and Niemelä (1985). As a result, Skeletocutis suddenly turned out to be a large genus containing almost 20 species (eventually certainly even more). Its affinities with Tyromyces became obvious, especially since David (1982) reported Skeletocutis38 type encrustations in the mycelium of $T$. chioneus (Fr.: 39 Fr.) Karst. as well. At present it seems that to merge 
all this material into one genus would give too heterogeneous an entity, while, on the other hand, the old genera have lost their relevance. Only the future will show how this complex and its allies (e.g., the genus Piloporia Niemelä, Gelatoporia Niemelä, Poria lenis (Karst.) Sacc., P. rivulosa (Berk. \& Curt.) Cooke, $P$. mentchulensis Pilát) should be regrouped in order to make up a harmonious entity. Although the present status of Skeletocutis may be controversial, it is most gratifying to note that the finding of similarities between this genus and Incrustoporia gave a strong stimulus to the European taxonomy of polypores, dissipating the static feeling which had long prevailed. It also showed that there is still a considerable amount of work to be done at the specific level of the polypores.

\section{Materials and methods}

This paper deals with the specific characters, generic positions and nomenclatural problems of the species rather than with their distributions, and no great effort was made to obtain a complete picture of the ranges. The Finnish specimens studied are deposited in H, HFR and TUR, and the reference herbaria of Heikki Kotiranta (shortened as H.K.) and Tuomo Niemelä (T.N.). Types and other important specimens were received from K, LY, NYS, O, PAC, PRM, S, SYRF, TAA and UPS.

The methods mostly follow those adopted in the previous papers in the series. A major difference is the new method of expressing the microchemical reactions:

IKI stands for Melzer's reagent, which shows an amyloid (IKI grey or IKI blue) or dextrinoid (IKI red) reaction (unspecified positive reaction indicated by $\mathrm{IKI}+$ ), or no colour changes (IKI-). Cotton Blue (CB) shows cyanophily $(\mathrm{CB}+$ ) or acyanophily $(\mathrm{CB}-)$. Cresyl Blue (CRB) displays metachromatism (CRB+) or no colour change reactions (CRB-). Lactophenol (LP) was used only exceptionally. $\mathrm{KOH}$ means $5 \%$ potassium hydroxide, unless the concentration is otherwise indicated.

The shortened way of expressing the reactions was felt necessary to make the species descriptions more compact. The reactions often have to be indicated separately for the cotextual hyphae, tramal hyphae, spores, etc., which greatly lengthens the text. The abbreviation IKI has been used earlier, for instance by Lowe (1966): Melzer's reagent contains a mixture of iodine (I) and potassium iodide (KI). The description IKI red is only approximate and includes brownish hues. More accurate colour terms can be used if needed.

In my studies, $\mathrm{CB}$ was prepared according to the formula of Singer (1975), by using water-soluble Aniline Blue from the Merck Laboratories (Art. 1275), which gives somewhat stronger reactions than many other brands.

$\mathrm{CRB}$ is a $1 \%$ aqueous solution of Brilliant Cresyl Blue (Merck Art. 1280). The metachromatic reaction $(\mathrm{CRB}+$ ) consists of a reddish colour change; the reaction is absent $(\mathrm{CRB}-)$ if the structures remain pure blue. Sometimes the reaction is weak, intermediary or variable, which decreases the usefulness of CRB in certain cases. Tortic (1976) has studied this dye with larger material. The colour change seems to be due to a simple reaction: in the laboratory I found it was regulated by the $\mathrm{pH}$. In acid solutions the colour is blue, and the change to lilac starts around $\mathrm{pH}$
11.5. At $\mathrm{pH} 12$ a red colour has developed and remains if the $\mathrm{pH}$ rises further. The reaction is reversible. In practice, of course, other chemical properties may contribute to or govern the colour shift. We know extremely little about the chemical basis of the behaviour of most dyes commonly used in microscopy. But because of the simplicity of the reaction, I recommend that this feature be used with some caution, as supportive rather than conclusive evidence.

\section{Gelatoporia Niemelä, n.gen.}

Carposomata annua, resupinata, systema hypharum monomiticum, hyphae fibulatae, gelatinosae in tubulis vel subiculis inferioris, sporae cylindricae, cariem albam producunt. Typus: Poria subvermispora Pilát.

Fruit bodies annual, resupinate, light-coloured; tubes soft and hygrophanous when fresh. Hyphal system monomitic; hyphae with thin or slightly and evenly thickened walls but lacking solid side branches or other differentiated hyphal types, hyaline, with clamp connections, $\mathrm{CRB}+$, glued together into a gelatinized structure in dry tube dissepiments, adjacent subiculum or both; dissepiment structure often layered with special medullary hyphae; hymenial cystidia absent, but bottle-shaped cystidioles sometimes present; spores cylindrical, IKI-, CB-. Causing white-rot on both coniferous and deciduous trees.

The erection of the new genus was felt necessary, even though it is undesirable to burden the polypore system with new small genera. It was prompted by the situation of Poria subvermispora, which did not find a natural place in any of the existing genera. Domański (1969) proposed Fibuloporia for it, but that genus is characterized by species with subglobose and very small spores, cottony-corky structure, straight and spaced hyphae, small and conical clamp connections, perenniality, and many other alien features. In fact, the two taxa are connected by little more than the resupinate growth habit, light colour and white-rot.

Tyromyces, proposed by Ryvarden (1973) for the species, was at that time considered to comprise most of the monomitic, light-coloured, annual polypores, causing predominantly brown-rot. So $P$. subvermispora did not fit well within its scope. After the studies of David (1980), however, Spongiporus (which produces brown-rot) and Leptoporus (with brown-rot and simple-septate hyphae) were separated from Tyromyces, which was left with only two species: $T$. chioneus as the type, and T. kmetii (Bres.) Bond. \& Sing. In this restricted sense it turned out to include taxa which produce white-rot and whose context contains special, solid, rather short hyphae besides the dominant thinwalled ones. Thus Tyromyces emerged as a possible genus for $P$. subvermispora. At present, however, I am inclined to exclude $P$. subvermispora from that genus, because all the known species of Tyromyces s.str. are fleshy, able to produce pilei, their context is formed by special coralline hyphae, which are predominantly CRB negative, and their tube structure is uniform, non-hygrophanous and not gelatinized on drying. Besides, T. chioneus is dimitic.

Some degree of gelatinization is found in Skeletocutis, too. The core of that white-rot-causing genus 
consists of dimitic or 'pseudo-trimitic' species, but David (1982) introduced monomitic species into it as well. They all share a special kind of encrustation (Keller 1979), not found in Gelatoporia. I am not quite convinced about the suitability of including monomitic species in Skeletocutis; anyhow Gelatoporia cannot be included in Skeletocutis s.str., or Leptotrimitus, Incrustoporia or Piloporia, which are all dimitic or 'pseudo-trimitic'.

The genus Gloeoporus (sensu Ryvarden \& Johansen 1980) deserves consideration, especially since it has long included $P$. pannocincta. Gloeoporus is characterized by a merulioid hymenium, which lines the pore mouths in a continuous layer. On account of this feature, Gloeoporus is generally regarded as a distant relative of the true pore fungi.

Rigidoporus (incl. Physisporinus) and Henningsia (Ginns 1979) resemble the new genus in often being hygrophanous-gelatinous, in having a monomitic structure and bottle-shaped cystidioles, and in causing white-rot. However, they have globose spores and are consistently clampless. The latter feature is further supported by the absolute lack of clamp connections in the related Oxyporus and Leucophellinus (Parmasto 1983), and seems to have considerable value in that group.

Bjerkandera resembles Gelatoporia in having gelatinous tubes (B. adusta (Willd.: Fr.) Karst.) or a gelatinous layer above the tubes ( $B$. fumosa (Pers.: Fr.) Karst.), cyanophilous hyphae and white-rot, but differs in producing pilei, having robust contextual hyphae with prominent clamp connections and another spore type. Further, the gelatinized (or rather, resinous) parts of Bjerkandera look quite different in the microscope, being formed of tortuous hyphae glued together with coloured matter (which gives a grey tone to the pores), instead of the tightly arranged, subparallel hyphae.

Ceriporiopsis is a genus with white-rot-causing species. In contrast to Gelatoporia, its species have fragile and non-hygrophanous tubes, whose structure does not differ sharply from that of the subiculum. Their spores are reniform to ellipsoid, have another type of basidium and no cystidioles.

Dichomitus, Diplomitoporus and Flaviporus, though causing a white-rot, exhibit a strong dimitic hyphal structure, which has no equivalent in the genus Gelatoporia.

As only a few species are now ascribed to Gelatoporia, the less critical characters of the genus may still change. If roundish spores are acceptable, Poria rivulosa (Berk. \& Curt.) Cooke seems to belong here. The cultural characters of $P$. subvermispora and $P$. rivulosa are surprisingly similar (Stalpers 1978, Nakasone 1981), and the latter has gelatinous tubes and prominent cystidioles. Poria mentchulensis Pilát, too, seems to be connected with the new genus.

\section{Gelatoporia pannocincta (Romell) Niemelä, n.comb.}

Polyporus pannocinctus Romell, Arkiv Bot. 11(3): 20, 1911. Holotype (the only specimen mentioned): 'Polyporus pannocinctus, [Sweden,] Torne Lappm., Jukkasjärvi, Kalixfors,
Betula, 18.VIII. 1910 Romell '(S 13234, examined). Isotype: BPI 44208 ('lectotype', Lowe 1966: 72). - Poria pannocincta (Rom.) Lowe, N.Y. State Coll. For. Tech. Publ. 65: 55, 1976. - Gloeoporus pannocinctus (Rom.) Eriksson, Symb. Bot. Upsal. 16(1): 136, 1958. - Tyromyces pannocinctus (Rom.) Kotl. \& Pouz., Ceská Mykol. 18: 65, 1964.

Leptoporus bourdotii Pilát, Bull. Soc. Mycol. France 48: 167,1932 . Several specimens mentioned without indication of the type; lectotype: [U.S.S.R.,] Carpatorossia, Zamer, Kobylecka Polana, Fagus sylvatica, VII.1929 Pilát (PRM 33843 , sel. Kotlaba \& Pouzar 1964). - Poria bourdotii (Pil.) Pilát, Glasnik Skops. Naučn. Družstva 18: 191, 1938. Gloeoporus bourdotii (Pil.) Bond. \& Sing., Ann. Mycol. 39: 52, 1941 (comb. inval.: no basionym indicated); Bondarcev, Trut. Griby Evrop. Casti SSSR i Kavkaza: 257, 1953.

Leptoporus zameriensis Pilát, Bull. Soc. Mycol. France 51: 256, 1936 ('1935'). Lectotype: [U.S.S.R.,] Carpatorossia, Zamer, Kobylecka Polana, Fagus, VIII.1929 Pilát (PRM 38318 , sel. Kotlaba \& Pouzar 1964).

Poria tacamahacae Baxter, Pap. Mich. Acad. Sci. Arts Lett. 24: 169, 1939 ('1938'). Holotype: Canada, N.W.T., Fort Smith, Populus basamifera, 20.VIII.1937 Baxter 23155b $(\mathrm{MICH})$.

Not Podoporia confluens Karst., Hedwigia 31: 297, 1892. The holotype ( $\mathrm{H} 817)$ is conspecific with Polyporus cerifluus Berk. \& Curt. (det. T. Niemelä 1980 in herb.); Lowe (1956, 1966 ) indicated that it is possibly synonymous with $G$. pannocincta.

Evidently not Polyporus hyalinus Berk., Flora Tasman.: 255, 1860. Lectotype: 'Tasmania, Herb. Berkeley 1879' (K, examined). Ryvarden and Johansen (1980) regard it and Pol. pannocinctus as 'almost certainly the same species'. Discussed below.

Fruit body annual, resupinate, ellipsoid or irregular, (4-) $12-20 \mathrm{~cm}$ in longest dimension (sometimes even longer), at centre $1-6 \mathrm{~mm}$ thick. Sterile margin $1-5 \mathrm{~mm}$ wide, papery thin, not rhizomorphic, creamwhite, weakly lustrous when dry; similar sterile areas also in oblique parts and on mycelium surrounding adjacent grasses and other debris; sterile areas distictly paler than the pores. Poroid areas even, cream with greenish or olivaceous tint, bruised parts ochraceous; darkening only slightly on drying or turning yellowish or dull greyish ochre according to the drying conditions and age of the fruit body. Pores round, 68 per $\mathrm{mm}$. Consistency watery when fresh, tubes splitting easily; hardens to horny on drying but retains shape well, except in oldest parts, where tubes split into $\mathrm{v}$-shaped or roundish fissures. Odour pungent, taste slightly bitter.

Section: Subiculum distinct, $1-2 \mathrm{~mm}$ tick, white to straw, woody when dry; with thin, brownish line above the tubes. Tubes when fresh greenish-white, watery hygrophanous, when dry pale olivaceous, waxy-translucent, rigid.

Hyphal system monomitic, generative hyphae hyaline, with clamp connections, not expanding in $\mathrm{KOH}$ but walls slightly swelling inwards in subiculum. Subiculum three-layered: upper, thickest layer with spaced, branched, intermixed hyphae, $4-5 \mu \mathrm{m}$ in diam, walls evenly thick $(0.7-1 \mu \mathrm{m}), \mathrm{CRB}+, \mathrm{CB}+$, IKI-; thin layer with similar hyphae, except very densely packed and $\mathrm{CB}-$; lowest layer gelatinized so that only the lumina of the hyphae visible (clearest in $\mathrm{CB}$ ), hyphae flexuose, changing gradually into the compact and parallel tramal structure. Dissepiments with gelatinized, parallel hyphae, $3-4 \mu \mathrm{m}$ in diam, 


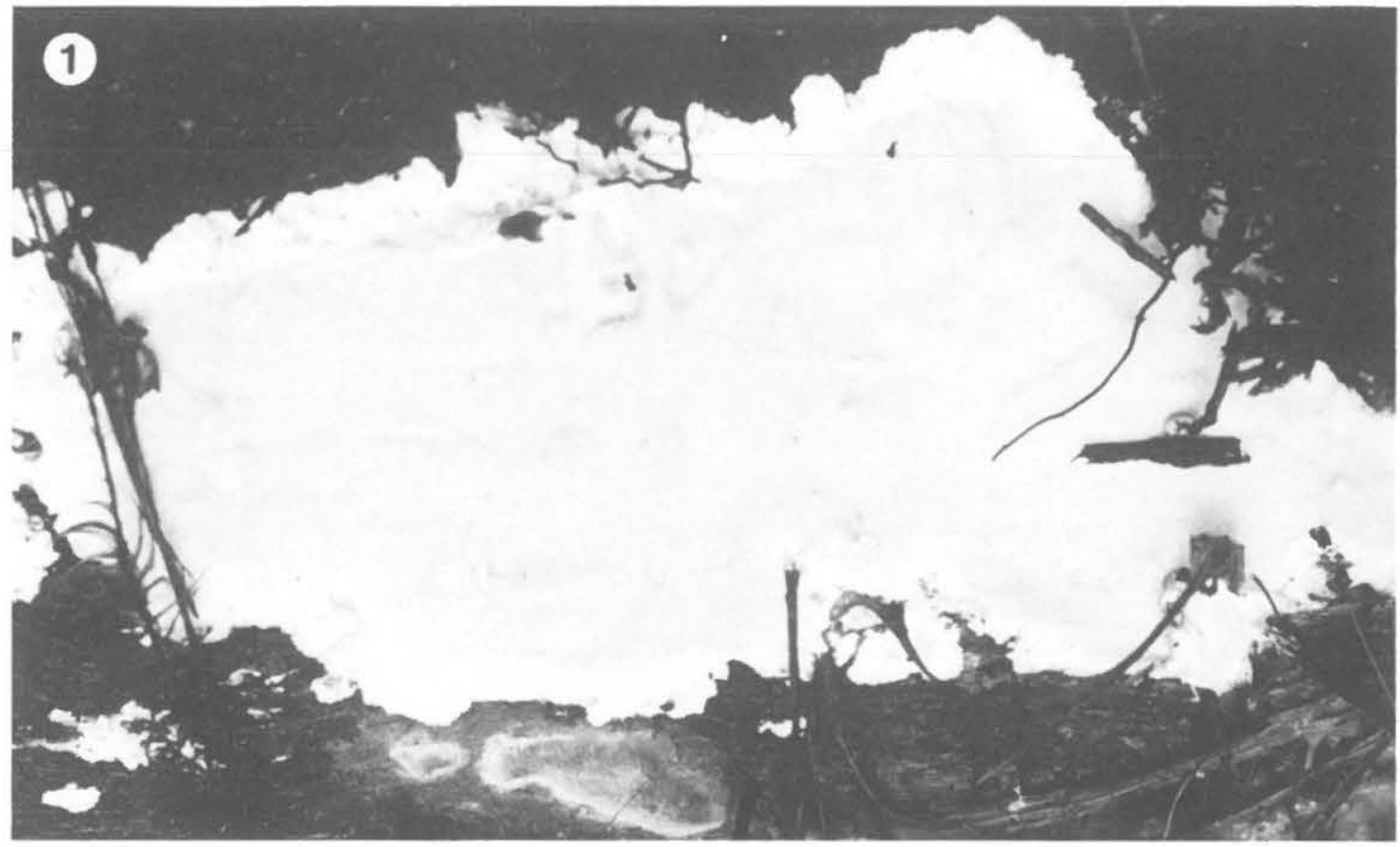

Figs. 1-2. Gelatoporia pannocincta, photographed in situ. - 1: Fruit body from a horizontal lower side of a fallen trunk, $\times 1.3,-2$ : Fruit bodies from oblique trunk side, $\times 1.5$ (Niemelä 1477 , T.N.).

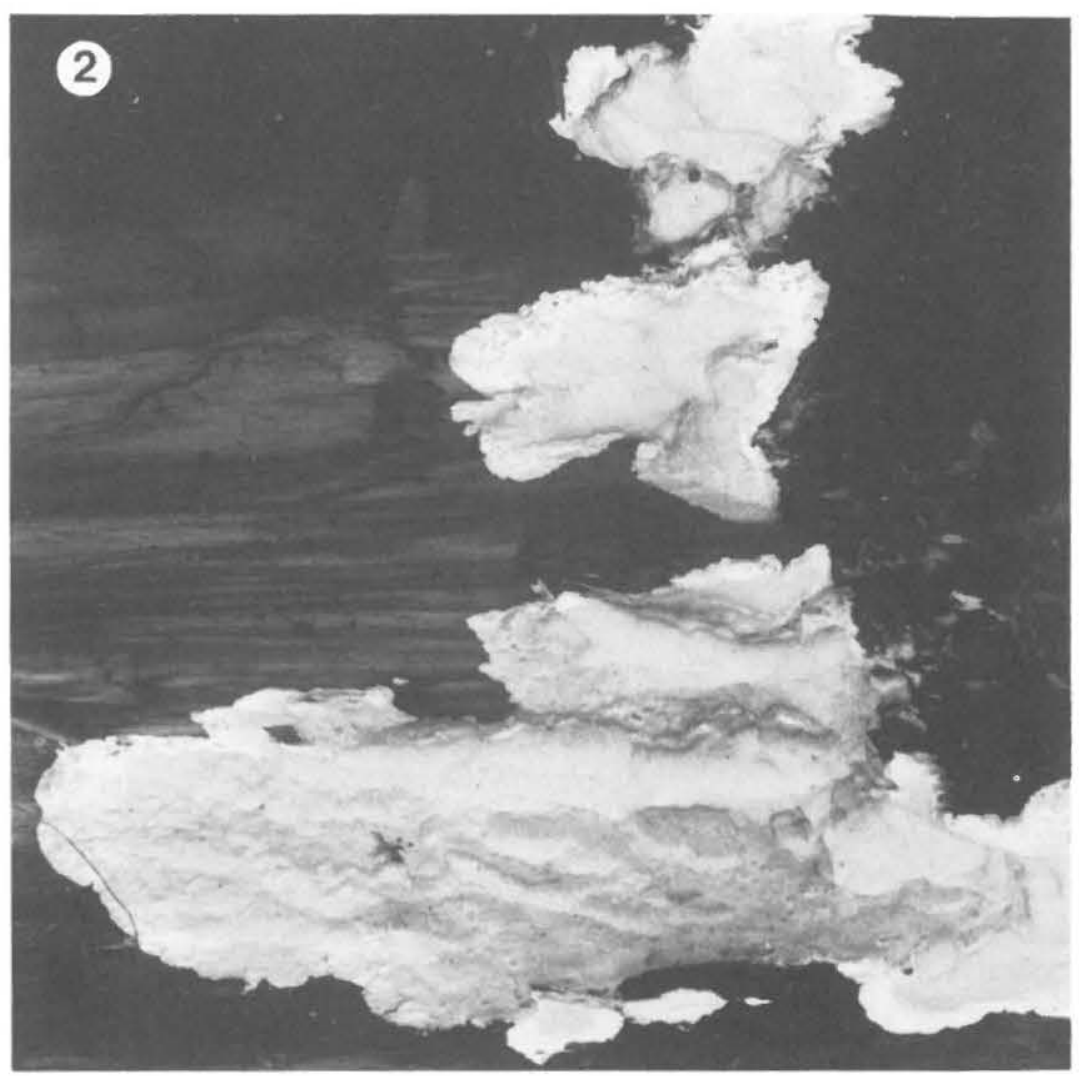




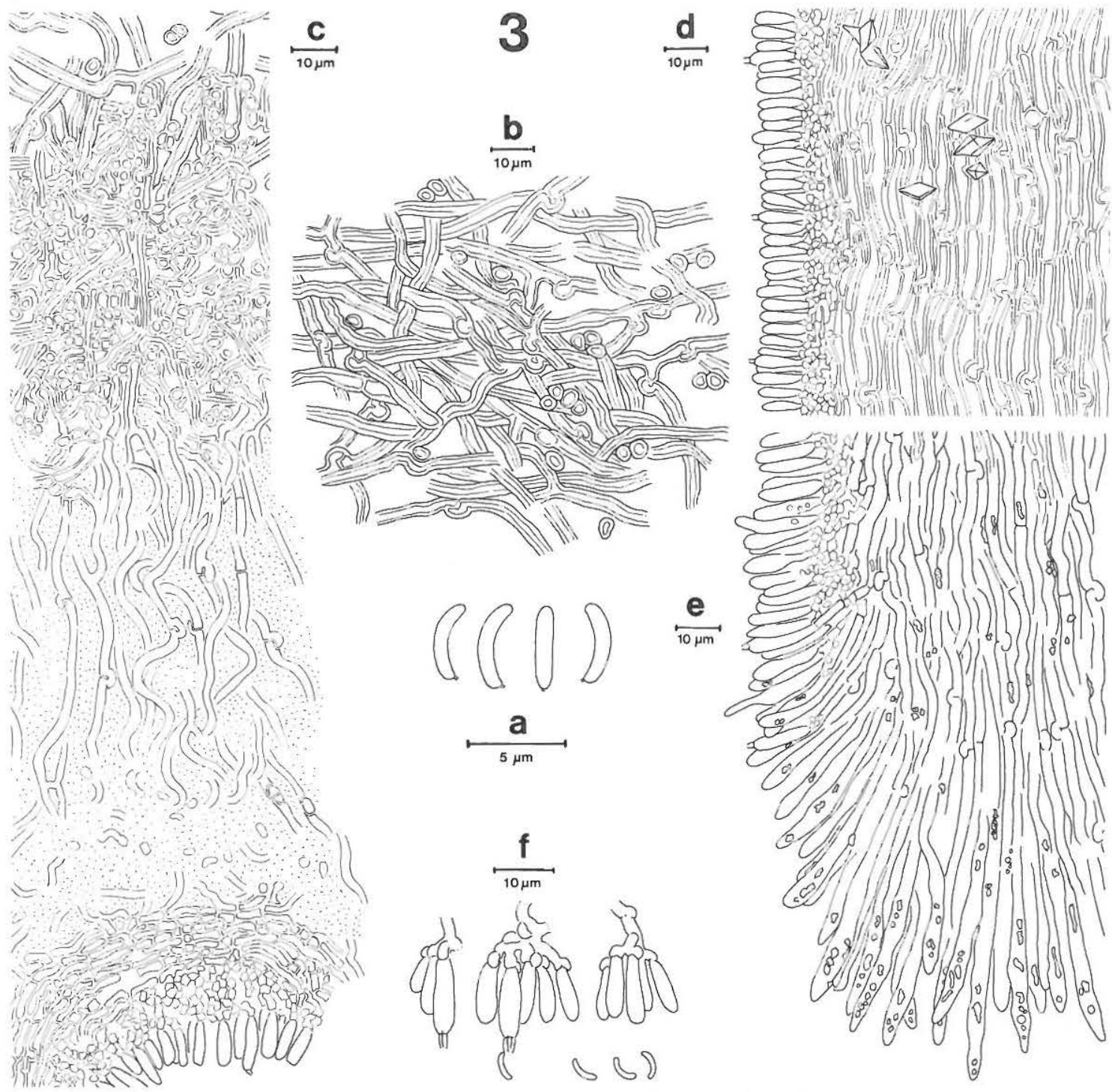

Fig. 3. Gelatoporia pannocincta. a) spores, b) hyphae from upper part of the subiculum, c) section through lower subiculum, showing a densely packed layer, jelly-like layer with sparse hyphae, and tube bottom, d) dissepiment in vertical section, e) dissepiment edge, f) basidia, basidioles and subhymenial hyphae. Drawn in CB (a-e) and in KOH (f) (Niemelä 1477, T.N.).

with rather thin walls, $\mathrm{CB}-$, IKI-, CRB variable, often with crystal rods or rosettes. Subhymenium 3$5 \mu \mathrm{m}$ thick (in $\mathrm{KOH}$ ca. $10 \mu \mathrm{m}$ ), parenchymatous, with isodiametric, thin-walled hyphal cells, $1-1.5 \mu \mathrm{m}$ in diam. Dissepiment edges with slightly swollen, fusiform hyphal tips, having granulous contents. Hymenium formed by rather dense palisade of narrow-claviform basidia $(9-13 \times 2.5-3.5 \mu \mathrm{m})$ and basidioles, no cystidioles seen. No hyphal pegs. Spores narrowly cylindrical to allantoid, thin-walled, 3.9$4.2(-4.5) \times 0.8-0.9 \mu \mathrm{m}, \mathrm{IKI}-, \mathrm{CB}-$ (contents blue).
On fallen trunks of angiosperms, in the study area mostly Betula, Populus and Alnus; exceptionally on gymnosperms. Causes extensive white-rot, uniform or splitting along the annual rings.

\section{Identification}

$G$. pannocincta is fairly easily identified by its macroscopic characters alone. The best field characters are the pale greenish-cream colour, small pores and the thin line above the tubes (visible under lens). In the microscope the narrow spores are diagnostic; the 
dissepiment structure is so characteristic that once it is learned the species can easily be identified in the sterile stage as well.

The succulent consistency is striking in the fresh stage; the contrast between the light margin and coloured pore area becomes even clearer during drying.

Extensive studies of the species have been made, e.g., by Eriksson (1958), Kotlaba and Pouzar (1964), Domański (1966, 1970), David (1972) and Ryvarden (1976).

\section{Taxonomy}

The specific status of $G$. pannocincta has been clear since the thorough study of Eriksson (1958). However, different opinions have been expressed on the proper genus. Eriksson's proposal of Gloeoporus received substantial support from Domański (1966), and many other authors (David 1972, Donk 1974, Jülich 1984, etc.) have accepted that genus. Kotlaba and Pouzar (1964) preferred Tyromyces (in the old sense, see the discussion of Gelatoporia above), but Kotlaba (1984) returned to the former genus. Ryvarden (Ryvarden \& Johansen 1980) studied this problem extensively, coming to the conclusion that the present species should be separated from Gloeoporus as it appears in the type $(G$. conchoides Mont. $=G$. thelephoroides (Hook.) Cunn.) and in G. dichrous (Fr.: Fr.) Bres. I share the opinion of Ryvarden.

If the initial stage of Gloeoporus (e.g., G. dichrous) is studied, the hymenium is seen to develop in a merulioid way. This can be observed in the very margin of a growing pileus, just outside the visible pore area. An even hymenium has already developed there, with a refractive subiculum, on a thick and jelly-like basal layer. Sections from the slightly older area show that the basal layer starts to thicken at regular intervals, pushing the hymenium and its subiculum outwards and so finally forming what appears to be a folded hymenium, or tubes. In the mature stage the hymenium of the dissepiment edges becomes somewhat differentiated (the reason may simply be exposure to the open air), causing the white pruina of the tube mouths. But even then it resembles normal hymenium more than the sterile dissepiment edge of a typical polypore: it is still composed of a palisade of short, equal cells, and not of long hyphal tips forming a continuation of the inner tramal stucture.

The initial structure of $G$. pannocincta is different. Its young surface just outside the poroid area is covered with long, undifferentiated hyphal tips, with granulous contents. The tubes are initiated as shallow cups, and dissepiments start growing downwards in between them (Bondarcev 1953 also described this process). The hymenium becomes differentiated only in the course of that process, first at the cup bottoms, and then along the dissepimental walls, but always well behind the advancing dissepiment edge. The hymenial cells are short and non-granulous, and clearly separated from the sterile hyphal tips. So the dissepiment growth is apical in $G$. pannocincta, as is normal in a polypore hymenophore (Corner 1953). In Gloeoporus the growth is caused by the extension of the deeper layers, and the necessary widening of the hymenial area is evidently achieved by intercalary growth. Further, the hymenium of $G$. pannocincta is thin and inconspicuous, formed by compact, shortlived cells. In Gloeoporus it is thick and elastic, composed of very densely packed, slender-based, persistent basidia and basidioles.

I regard these differences in ontogeny between the two groups as sufficient to justify placing them in different genera. Whether $G$. pannocincta is congeneric with $G$. subvermispora and its relatives in the strictest sense is a question which may well be raised in the future. At present I am not prepared to undertake any further splitting.

I was unable to solve the identity of Polyporus hyalinus Berk. with certainty. Ryvarden and Johansen (1980) regard it as a probable older name of the present species. The type is very small and badly preserved; the spore type could not be ensured. Tramal hyphae are $1.5-2.5 \mu \mathrm{m}$ in diam, sclerified and freely oriented. Subiculum is dimitic, with thinwalled generative hyphae $(2-2.5 \mu \mathrm{m}$ in diam, clamp connections) and solid skeletals. I could not find any reliable similarities between it and $G$. pannocincta, and propose that they are kept apart, unless new evidence is found.

\section{Ecology}

$G$. pannocincta is a saprophyte of fallen, preferably thick tree trunks. In Fennoscandia, two-thirds of the collections have been made from birches (Betula pendula and $B$. pubescens) and most of the others from aspen (Populus tremula); a few collections originate from alder (Alnus incana, A. glutinosa) and two from Picea abies. In Central Europe, the majority of the records $(74 \%)$ are from Fagus sylvatica (Kotlaba 1984). The species has also been recorded in Europe from Acer platanoides, A. pseudoplatanus, Carpinus betulus, Fraxinus angustifolia, F. excelsior, Populus nigra, Quercus petraea, Q. robur, Salix, Tilia cordata and Ulmus montana. Picea abies was mentioned by Eriksson (1958), Parmasto (1957, 'rarissime'), Järva \& Parmasto (1980) and Kotlaba (1984, one record out of 65), and seems to be an exceptional but confirmed host of $G$. pannocincta. Telleria (1980) reports Pinus insignis and Kotlaba (1984) Abies alba.

Birches (B. ermanii, B. japonica) and alder ( $A$. hirsuta) are common hosts of the species in the Soviet Far East (Parmasto 1963b). In North America it seems to favour Populus: $P$. tremuloides, $P$. grandidentata (Lindsey \& Gilbertson 1978), P. balsamifera and $P$. trichocarpa (Baxter 1939). Kotlaba and Pouzar (1964) reported it from Carya also.

G. pannocincta is rather exacting as regards its biotope. The sites known to me were shady, rich forests with a closed stand of tall spruce intermixed with deciduous trees. The field layer should largely consist of grasses, and the soil should preferably be moist but well drained. Favourite sites, especially in the north, are on the lower parts of slopes in grassherb forest bordering brooks. The species is a slow 


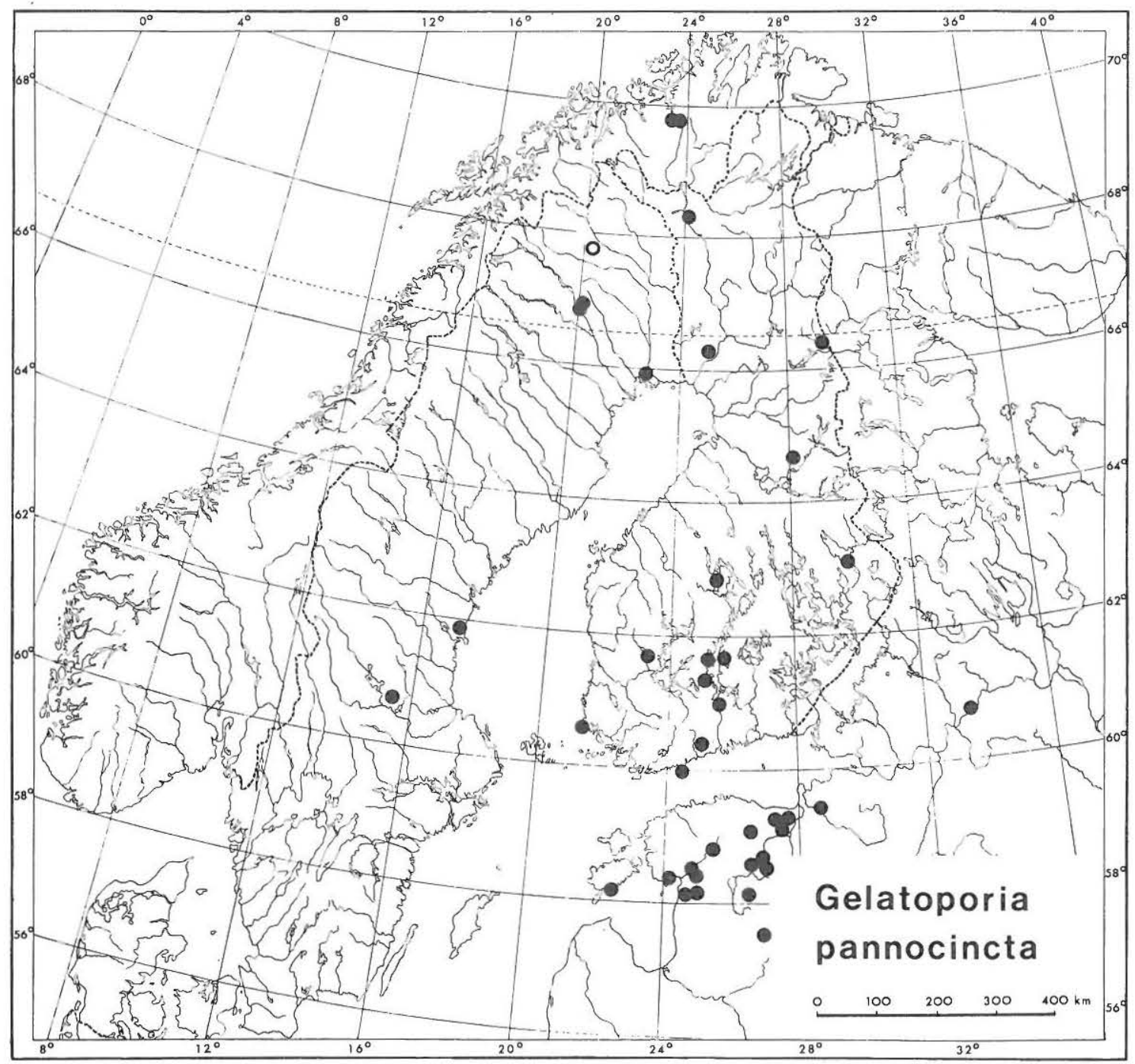

Fig. 4. The distribution of Gelatoporia pannocincta in NW Europe, based on the specimens examined and on selected published records (see text). The open circle indicates the holotype locality.

grower, appearing on fallen, partly decorticated logs which have lain on the ground for many years and absorbed a great deal of moisture. Such conditions are seldom found outside national parks or other forest reserves. For this reason the future of the species deserves attention in Finland, as well, although it is not a rarity at present.

A danger for the future of such slow-growing saprophytes lies in the current practice of removing decayed, fallen trees from the forests during routine forest management. The decayed logs are of little use, and their removal seems to be based on the fear that they would serve as a growth substrate for parasitic fungi. In fact, however, they mostly support saprophytic fungi, most of them harmless or even beneficial as competitors or more harmful species.

At least in North Europe, G. pannocincta seems to grow almost exclusively on trees which have been decayed by some other, white-rot-causing, parasitic fungus. Most collections were made from trees with dead fruit bodies of Fomes fomentarius (L.: Fr.) Fr. or Inonotus obliquus (Pers.: Fr.) Pilát. Parmasto (1959), Tortić \& Kotlaba (1976) and Kotlaba (1984) also report a connection with Fomes fomentarius. These trees often hosted other resupinate, living polypores, too: Gloeoporus dichrous and in one case Oxyporus corticola (Fr.) Ryv.

$G$. pannocincta is a species which may easily remain unnoticed, if not specially searched for. As a rule the fruit bodies emerge only on the under-sides of 
the tree trunks, close to the moist ground. The logs are often wet, slippery and massive, so that their examination is apt to be incomplete. The numerous records in southern Finland and Estonia give the impression that the species is less rare in this area than is generally believed.

\section{Distribution}

The distribution of $G$. pannocincta in NW Europe is mapped in Fig. 4. For Sweden and Norway the information is taken from the studies of Eriksson (1958), Ryvarden (1971), Strid (1975) and Ryman (1984). The Finnish determinations and most of the collections have been made by Heikki Kotiranta and/ or myself, and some of these records have already been published (Kotiranta \& Niemelä 1981, Ulvinen et al. 1981). The records from the adjacent U.S.S.R. are according to Parmasto (1957) and Bondarceva (1964).

The species has an eastern distribution in this area. It is not known from Denmark (Ryvarden 1976), and is regarded as endangered in Sweden (Ingelög et al. 1984). In Finland it has been found scattered all over the country, and seems to be well established. In some localities it has been collected repeatedly during a period of many years.

In Central Europe, G. pannocincta has been reported from Poland (Domański 1972), the German Democratic Republic (Fischer 1979) and Czechoslovakia (Kotlaba 1984). Numerous records originate from the Mediterranean - Black Sea area: Spain (Tellería 1980), France (David 1972), Yugoslavia (Tortić \& Kotlaba 1976), Armenian S.S.R. (MelikHačatryan \& Martirosyan 1971), Crimea and Georgian S.S.R. (Bondarcev 1953). The species is also known from the Byelorussian S.S.R. (Komarova 1964), Ukrainian Carpathians (Kotlaba \& Pouzar 1964), the surroundings of Orel and Tambov south of Moscow (Bondarcev 1953), and the Komi A.S.S.R. (Parmasto 1963a) in the European U.S.S.R., and in its Asian part from Narym and Vasyugan (NW of Tomsk) by the River Ob (Parmasto 1963b, Kotlaba \& Pouzar 1964), Krasnojarsk on the northern slopes of the Sayan Mts. (Kotlaba \& Pouzar 1964), SikhoteAlin in Primorski Kraj, Soviet Far East (Gordienko 1979), and Kamchatka (Parmasto 1963b). It is widely distributed in North America (Baxter 1939 as Poria tacamahacae, Lowe 1966, Gilbertson et al. 1975, Lindsey \& Gilbertson 1878 , etc.), from the Slave River of the Northwest Territories, Canada, to Arizona and New Mexico in the southern U.S.A.

The total distribution of $G$. pannocincta extends much farther southwards, however, provided the species concept has been correctly understood. Ryvarden and Johansen (1980) report it from Kenya, Hallenberg (1979) from Iran, Hjortstam and Ryvarden (1982) from Thailand, and Kotlaba (1984) from Australia and New Zealand.

\section{Selected specimens examined}

Norway. Finnmark: Alta, 1970 Ryvarden $6659(\mathrm{O}, \mathrm{S})$. Sweden. Norrbotten: Råneå, 1972 Strid 10416 (S). Torne Lappmark:
Jukkasjärvi, 1910 Romell 13234 (S, holotype of Pol. pannocinctus). Finland. Varsinais-Suomi: Kustavi, 1980 Alava 19524 (TUR). Uusimaa: Kirkkonummi, 1964 Kujala \& Laine 4783 (HFR). Sipoo, 1978 Niemelä 1333 (T.N.) Satakunta: Viljakkala, 1968, 1969, 1970 Niemelä (H, T.N.). Etelä-Häme: Hollola, 1984 Haikonen 4810 (H). Lahti, 1980 Haikonen $651(\mathrm{H}), 1982$ Haikonen $3010(\mathrm{H})$. Padasjoki, 1979 Niemelä 1477 \& Kotiranta (T.N.), 1980 Kotiranta 2605 \& Koski (H, H.K.). Pohjois-Häme: Saarijärvi, 1984 Kotiranta 5396 (H.K.). Pohjois-Karjala: Pielisjärvi, 1956 Kujala (HFR), 1979 Niemelä 1656 \& Kotiranta (T.N.). Kainuu: Puolanka, 1979 Niemelä 1607 \& Kotiranta (T.N.). Pohjois-Pohjanmaa: Rovaniemi, 1970 Niemelä (T.N.), 1980 Kotiranta 2188 \& Niemelä 2076 (H). Kuusamo: 1983 Kotiranta 4779 (H.K.). Enontekiön Lappi: Enontekiö, 1980 Kotiranta 2341 \& Niemelä $2179(\mathrm{H})$.

\section{Gelatoporia subvermispora (Pilát) Niemelä, n.comb.}

Poria subvermispora Pilát, Studia Bot. Čechica 3:2, 1940. - Fibuloporia subvermispora (Pilát) Domański, Acta Soc. Bot. Poloniae 38: 453, 1969. - Tyromyces subvermisporus (Pilát) Ryvarden, Norwegian J. Bot. 20: 10, 1973. - Spongiporus subvermisporus (Pilát) Ryv. \& Gilbertson, Mycotaxon 19: $142,1984$.

Poria notata Overholts, Bull. Pennsylv. Agric. Exp. Sta. 418: 33, 1942 (nom. inval.: no Latin description). Cf. Lowe (1966) and Ryvarden \& Gilbertson (1984).

Fruit body annual, resupinate, mostly in roundish patches $0.5-2 \mathrm{~cm}$ in diam, which later fuse together, finally up to $2-5 \times 10-20 \mathrm{~cm}$ wide, $0.5-4 \mathrm{~mm}$ thick. When fresh white throughout, bruised parts (also parts touching grass, leaves, etc. during growth) turning slowly light smoky-brown; when dry strawcoloured or pale ochre; margin very thin, lacunose, arachnoid or adpressed, cottony, $0.5-1.5 \mathrm{~mm}$ wide, white and in dry state contrasting with the strawcoloured pore area. Pores round or angular, split in oblique position, (3-) $4-5(-6)$ per $\mathrm{mm}$, dry edges with white pruina. Consistency when fresh waterytough, tubes splitting easily; attached firmly to decorticated substrates but loosely to bark and then rolling into shapeless fragments on drying; hard and brittle when dry. Taste slightly sour but not bitter, odour fungoid, weak.

Section: Subiculum very thin, white, not hygrophanous. Tubes when fresh white and watery-hygrophanous, when dry straw-coloured and cut surface with waxy sheen.

Hyphal system monomitic, generative hyphae hyaline, with clamp connections, not expanding in $\mathrm{KOH}$ but walls swelling inwards (to leave a capillary lumen only). Subiculum with thin, densely packed basal layer, otherwise with uniform tissue of tortuous, branched, randomly oriented hyphae, $2-3.5 \mu \mathrm{m}$ in diam, walls slightly thickened $(0.4-0.8 \mu \mathrm{m}), \mathrm{CB}+$, $\mathrm{CRB}+$. Dissepiment layered: central parts with spaced hyphae, IKI grey (reaction slow!); tube cavities (also their bottoms) lined by a gelatinous layer, 20-35 $\mu \mathrm{m}$ thick and formed by closely glued hyphae. Subhymenium undifferentiated. Dissepiment edges with flexuose, freely projecting hyphae, their apices slightly swollen and covered by prominent crystal rosettes. Hymenium formed by dense palisade of slender basidia $15-16 \times 4.5-5 \mu \mathrm{m}$, basidioles $10-14 \times$ 

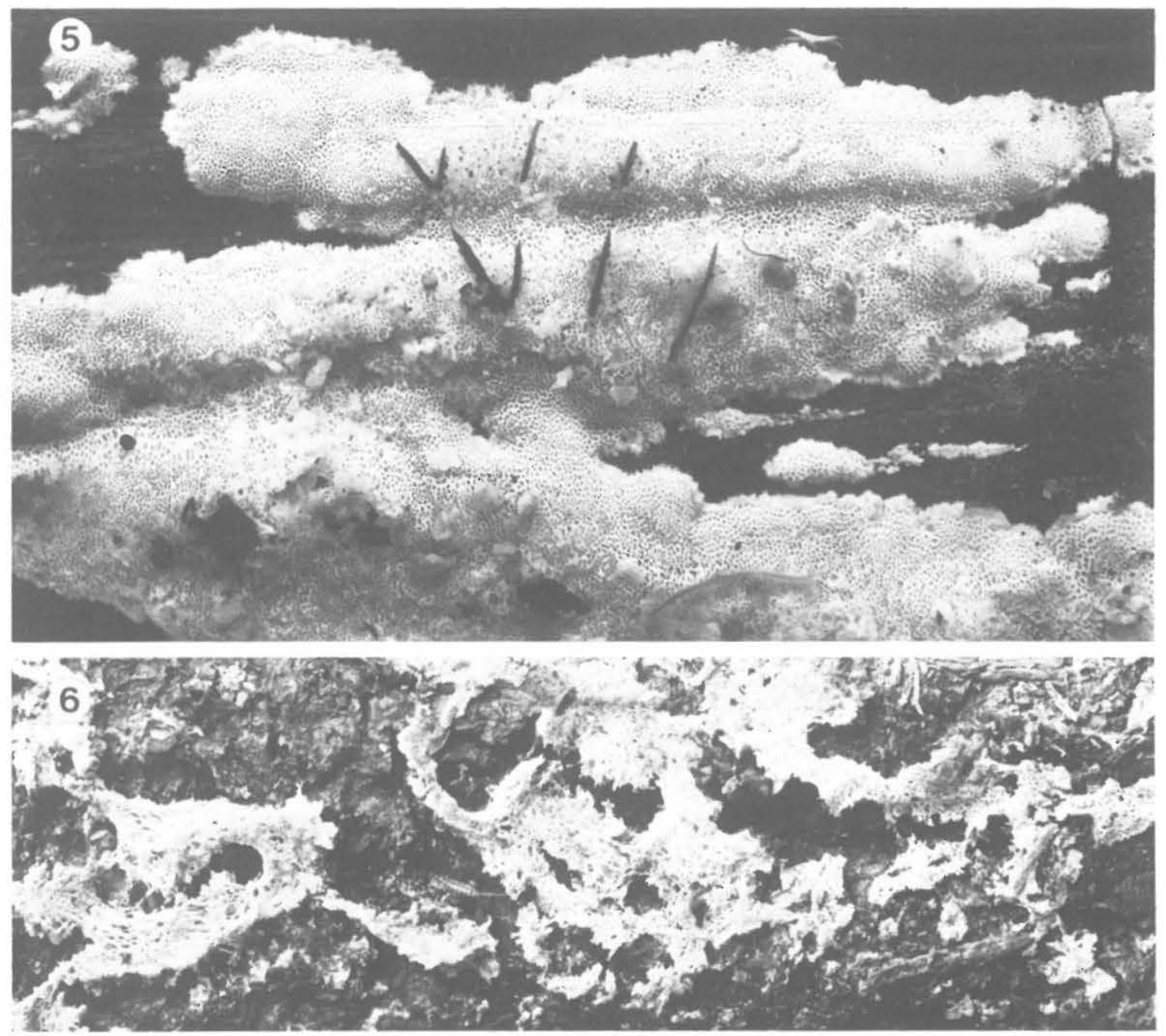

Figs. 5-6. Gelatoporia subvermispora. -5 : Fresh fruit body, $\times 2$. Parts touched by grass (at centre) have turned dark (Niemelä 2006, T.N.). - 6: Dry, constricted fruit body on spruce bark, X1.8 (Kotiranta 1512, H).

$4 \mu \mathrm{m}$, and poorly differentiated cystidioles with slender necks and roundish apices, measuring $11-15 \times$ $3-4 \mu \mathrm{m}$. Spherical crystal clusters sometimes occurring among the hyphae and in the hymenium. Hyphal pegs occasional, formed by swollen hyphae. Spores narrowly cylindrical, slightly curved, (4.5-) $5.1-6.1$ $\times 1-1.2 \mu \mathrm{m}$, walls thin and hyaline, IKI-, CB(contents blue).

On fallen trunks of gymnosperms (Picea abies), less often angiosperms (Prunus padus, Salix caprea) in moist sites, finally causing soft, stringy white-rot.

\section{Identification}

G. subvermispora is not easily identified by its external characters, and when fresh it may be confused with numerous other white, hygrophanous species of Poria. When dry, it develops a mealy pruina (caused by the encrusted hyphae) on the dissepiment edges, which helps identification. If the fungus is growing on bark, the formation of small, constricted fragments on drying points to this species, and experience of the fungus then allows its identity to be guessed with reasonable accuracy.

In the microscope $G$. subvermispora is very distinct. Few resupinate polypores have equally long and narrow spores. The best diagnostic character, however, is the presence of the encrusted hyphae at the dissepiment edges, first described by Domański (1969). They proved to be abundant in all the specimens studied, though Lowe (1966) did not mention them from the American material. The encrustation 


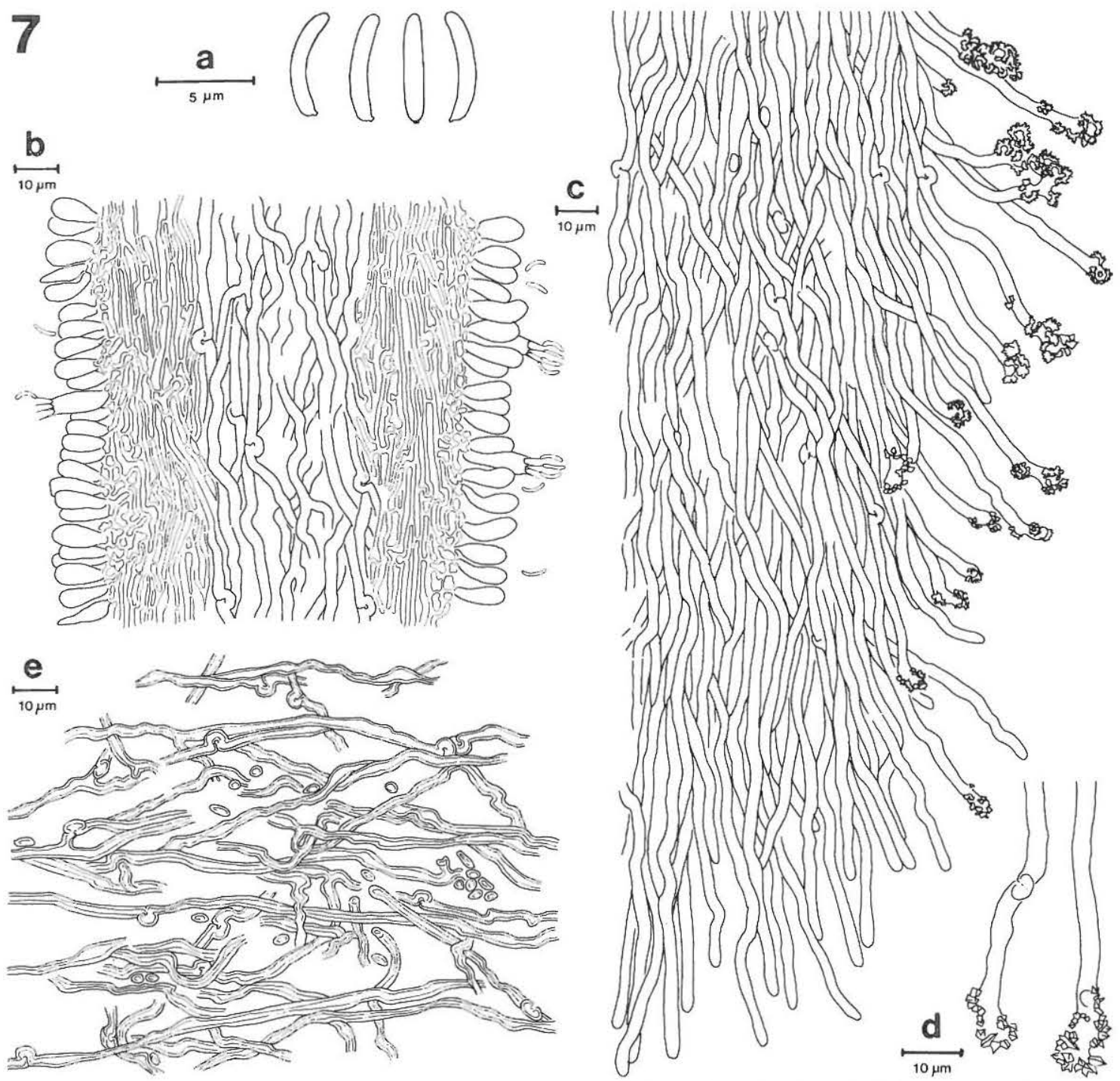

Fig. 7. Gelatoporia subvermispora. a) spores, b) dissepiment in vertical section, showing gelatinized subhymenial layers and spaced medullary hyphae, c) dissepiment edge, d) hyphal tips from the dissepiment edge, partly covered with crystals, e) section through subiculum. Drawn in CB (Niemelä 2006, T.N.).

is not uniform, but made up of neat, hemispherical rosettes close to the hyphal tips. Sometimes they occur all around the pore mouths, but often they are especially numerous on both sides of the dissepiment edges and absent from the downwards oriented midsection hyphae (Fig. 7 c). The crystals are polygonal in shape, and not of the pointed type found in the genus Skeletocutis: this was confirmed by SEM pictures.

The hyphal characters vary greatly, depending on the mountant used. I prefer $\mathrm{CB}$, which preserves the layered structure of the dissepiments. This feature is clearest in well-dried specimens, and seems to become indistinct with age; moreover, thin dissepiments lack the spaced, medullary hyphae. IKI swells the hyphae more distinctly, partly obscuring the gelatinous layer of the tubes, and making the subicular hyphae round in their transverse section. In CB the subicular hyphae are flattened, and cyanophilous especially in the American material. The amyloidity of the medullary hyphae of the dissepiments is weak, but observable if time is given for it to develop. The pore mouth crystals remain distinct in all the mounting media; crystal clusters scattered elsewhere in the fruit bodies may be of the same origin. 


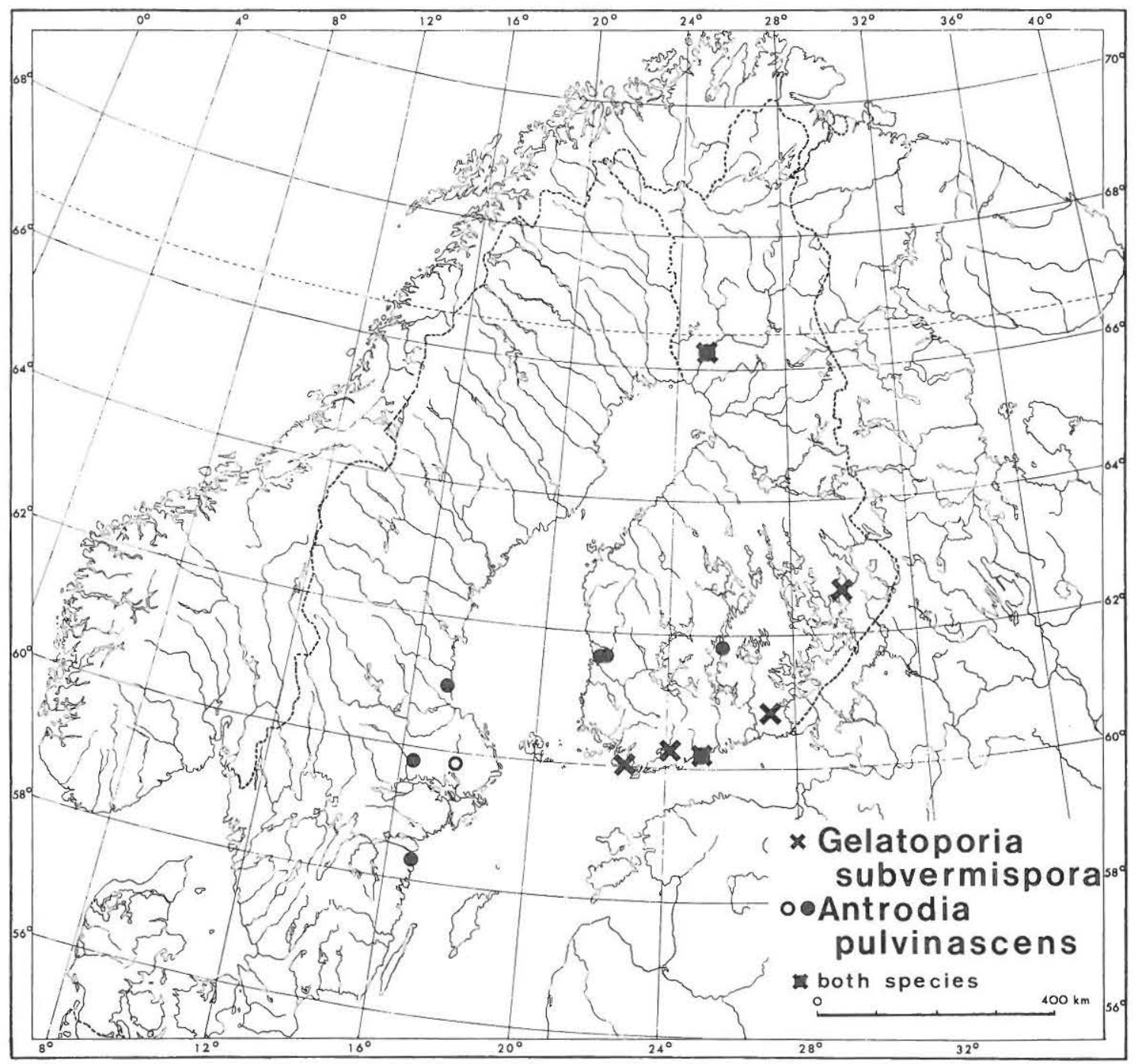

Fig. 8. Distributions of Gelatoporia subvermispora and Antrodia pulvinascens in Fennoscandia. The open circle indicates the holotype locality of $A$. pulvinascens.

\section{Ecology and distribution}

Although $G$. subvermispora prefers coniferous substrates, in Europe especially Picea abies, it also grows on hardwoods. From North America the following hosts have been reported: Picea engelmannii, Pinus contorta var. latifolia, $P$. ponderosa, Pseudotsuga menziesii, Acer sp., Populus tremuloides, Quercus alba, Q. laurifolia and Q. stellata (Baxter 1949 sub n. Poria quercuum Baxt.; Pilát 1940, Domański 1969, Gilbertson 1974, Gilbertson et al. 1975, Lowe 1966, Martin \& Gilbertson 1978, Nakasone 1981).

The habitats in Finland vary from grass-herb thickets with low mixed hardwood overgrowth, to closed, well-drained spruce forests. It seems that the species is not particularly exacting as regards its biotope, though it demands rather high moisture in the microclimate and substrate. The decay is wet, soft, stringy white-rot. Gilbertson et al. (1975) and Martin \& Gilbertson (1978) report brown-rot (this may be due to misidentifications, cf. 'Tyromyces' hibernicus (Berk. \& Br.) Ryv.), but Lowe (1966) suggests whiterot, as does also Nakasone (1981), who made extensive cultural studies on the species. The wet fruit bodies themselves are favoured by numerous insect larvae, which cause mature polypore individuals to disintegrate rapidly into a granulous mass.

In Fennoscandia $G$. subvermispora is known from Finland only, where finds have been made in almost all parts of the country and the species cannot be described as specially northern. Domański (1969) has reported it from the Białowieza National Park in eastern Poland. Tortic (1984) found it quite recently 
in Yugoslavia. The species is widespread in North America, having been reported at least from Arizona, Colorado, Florida, Georgia, Maryland, Missouri, New Mexico, New York, North Carolina, Oregon, Pennsylvania and Washington in the U.S.A., and from Ontario and Saskatchewan in Canada (see the references in the host tree list above).

\section{Specimens examined}

Finland. Varsinais-Suomi: Vihti, Picea abies, 16.VIII.1979 Kotiranta 1512 (H.K., T.N.). Uusimaa: Helsinki, Salix caprea, 22.VI.1984 Saarenoksa 4184 (H). Etelä-Savo: Luumäki, 5.IX.1979 Fagerström (H). Pohjois-Karjala: Joensuu, Prunus padus, 5. VIII. 1980 Niemelä 2000 (H, T.N.), 8.VIII.1980 Niemelä 2006 (H, T.N.). Pohjois-Pohjanmaa: Rovaniemi, Pisavaara National Park, P abies, 31.VII.1979 Niemelä 1573 \& Kotiranta (T.N.). Poland. Hajnówka: Białowieża National Park, $P$ abies, 9.VIII.1962 Domański 3859 (T.N.). U.S.A. Maryland: Beltsville, Quercus, 3.X.1958 Davidson \& Lentz 105272 (T.N.), 15.IX.1960 Davidson \& Gilbertson 90031 (T.N.).

\section{Tyromyces canadensis Overh. ex Lowe}

Polyporus canadensis Overholts, Mycologia 33: 97, 1941, nom.inval. (Art. 36). - Polyporus canadensis Overh. ex Lowe, Mycotaxon 2: 45, 1975, nom.inval. (Art. 34.1 a, d). - Tyromyces canadensis Overh. ex Lowe, Mycotaxon 2: 44, 1975. Holotype: 'Polyporus canadensis sp.nov., [Canada, Ontario,] Ottawa, Dow's Swamp, on spruce stump, 16.IX.1933 J.W. Groves 16860' (PAC, examined).

Antrodiella overholtsii Ryv. \& Gilbertson, Mycotaxon 19: 139, 1984, nom.illegit. (Art. 63). - Flaviporus overholtsii (Ryv. \& Gilbertson) Ginns, Mycotaxon 21: 326, 1984, nom.illegit.

Fruit body annual, pileate, applanate or fanshaped, sessile or attached to substrate with a constricted base (substipitate), $2-4 \mathrm{~cm}$ wide, projecting ( $1-) 2-3.5 \mathrm{~cm}$ from substrate, $2-5 \mathrm{~mm}$ thick. Upper surface initially with matted hairs and creamcoloured, but soon almost glabrous, with dense, radial, grey striae and the surface finally becoming mouse-grey; close to the base the striae bear solitary hairs. Edge thin and acute, inrolling strongly during drying. Pore surface evenly concave, cream-coloured to light ochraceous; pores angular, $5-6$ per $\mathrm{mm}$, with very thin dissepiments and lacerate mouths. Taste mild (collector's note).

Context in section white or greyish white, not layered, soft-fibrous, hardening to chalky when drying; tubes in section pale ochraceous or toffeecoloured, gelatinous-translucent (under lens), sturdy but tearing easily in the direction of their long axis, ca. $2 / 3$ of the total fruit body thickness, in consistency and colour contrasting slightly but very clearly with the context; darker and very thin $(0.02-0.04 \mathrm{~mm})$ dividing line sometimes visible between tubes and context.

Monomitic but appearing dimitic, generative hyphae with clamp connections. Context hyphae $\mathrm{CRB}+$ (variable), $3-5 \mu \mathrm{m}$ in diam, hyaline, sclerified or thin-walled but with numerous, finger-like, refractive (solid) side branches resembling skeletal hyphae; hyphae loosely intermixed in context, or arranged in indistinct, radial strands and intermixed in between. Hyphae of hairs and striae tightly agglutinated, thin-walled. Hyphae in dissepiments and in the dividing line above the tubes $2-4 \mu \mathrm{m}$ in diam, thin-walled, regular and glued tightly together, pale yellowish; crystal clusters $(3-5 \mu \mathrm{m}$ in diam) sometimes occurring among the hyphae in the lower dissepimental trama. Dissepiment edges with rather straight, adhering hyphal tips, often apically slightly swollen, occasionally with a few small crystals. Subhymenium thin and indistinct. Hymenium with rather dense palisade of short basidia $11-14 \times 4$ $5 \mu \mathrm{m}$, basidioles $9-11 \times 4-6 \mu \mathrm{m}$, and indistinct cystidioles $7-11 \times 4-5 \mu \mathrm{m}$, having bottle-like or conical tips and slightly thickened walls at basal parts. Hyphal pegs rare, narrow-based. Spores shortly ellipsoid to subglobose, hyaline, very thin-walled,
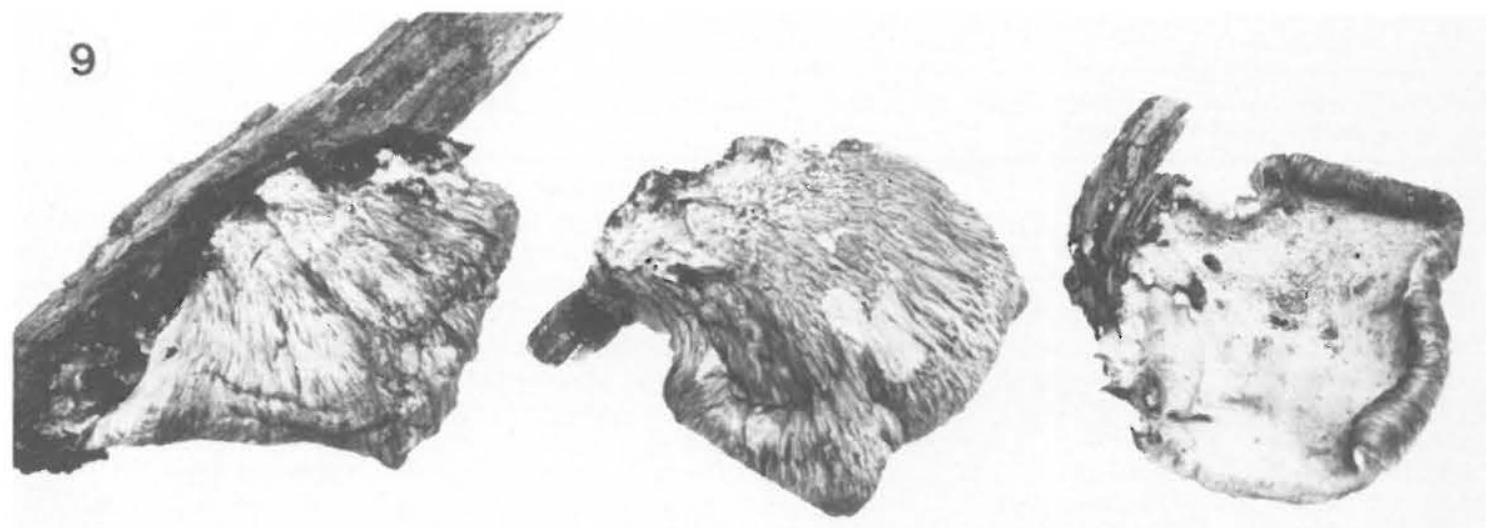

Fig. 9. Tyromyces canadensis, dry fruit bodies. Note the striate upper surface and inrolled margin. $\times 1.8($ Kujala 4260 , HFR). 


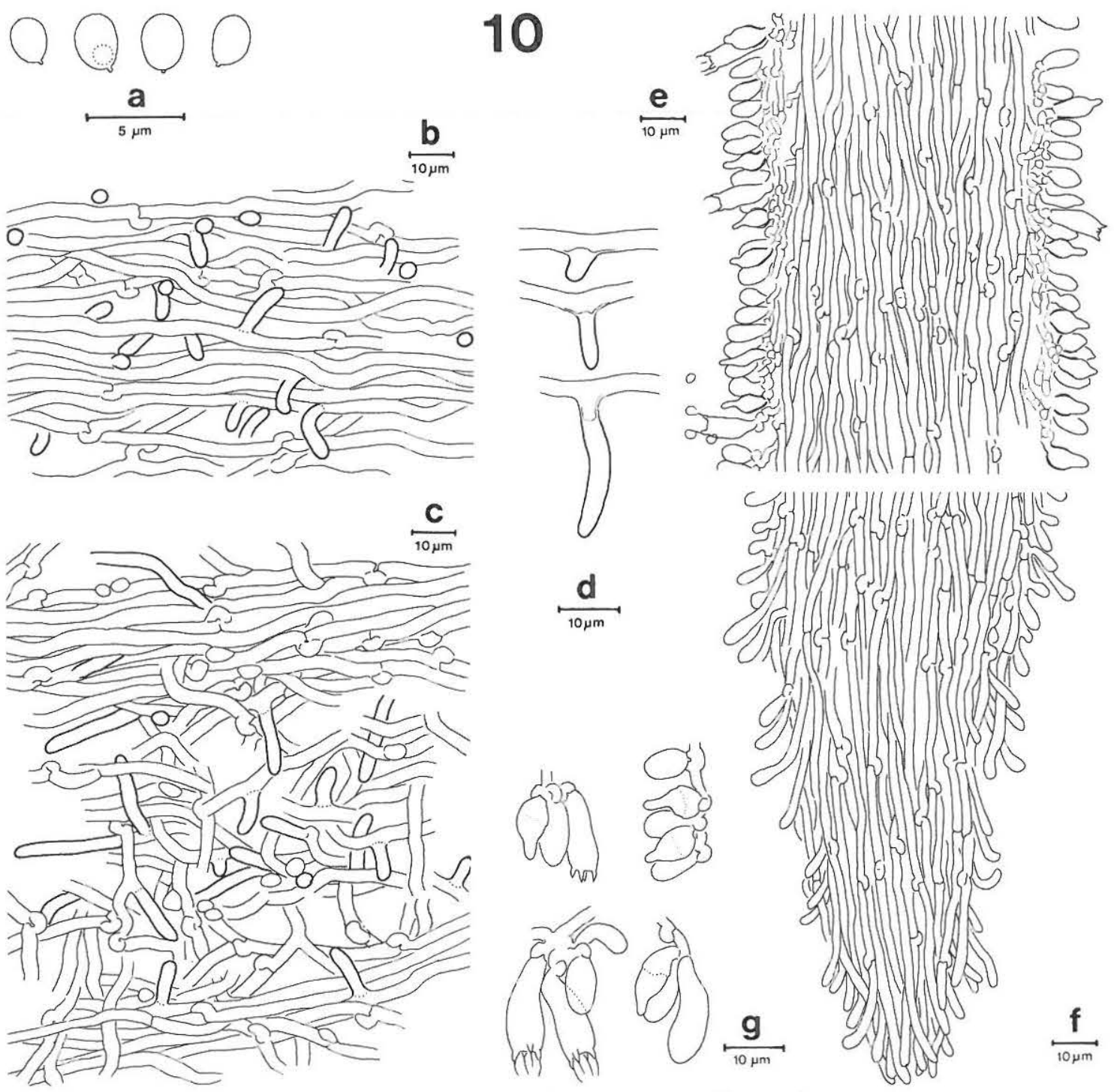

Fig. 10. Tyromyces canadensis. a) spores, b) section through young context close to the margin, showing the refractive side branches, c) strands and intermixed hyphae from old context, d) refractive side branches from context, e) dissepiment in vertical section, f) dissepiment edge, g) basidia, basidioles and bottleshaped cystidioles. Drawn in CB (Kujala 4260, HFR).

$2.5-3 \times 1.9-2.3 \mu \mathrm{m}, \mathrm{IKI}-, \mathrm{CB}-$ (contents faint blue).

On fallen trunk of Pinus sylvestris in humid forest, evidently causing white-rot.

\section{Notes on the species}

This is the first record of $T$. canadensis from Eurasia, and it is known from only a few localities in North America. The above description is based on the abundant Finnish collection, but the type and some other North American collections were also consulted to check the variability of the characters. In the microscope the specimens all appeared strikingly similar, but the gross morphology seems to be somewhat variable. The type specimen is more robust than the others (cap $6 \mathrm{~cm}$ wide, stipe-like base up to $1 \mathrm{~cm}$ in diam), but most of the American collections were small, like the smallest fruit bodies in the Finnish material. The striation and grey tones were clearer in Europe, many of the American specimens having sordid brown colours on the upper surface. Martin and Gilbertson (1978) mention a 'mousy grey' colour in the American material.

$T$. canadensis is fairly easily identified by its substipitate shape, mouse-grey and sharply and 
densely striped cover, pale ochraceous tube layer $v s$. greyish white context, and very small spores. Further microscopical characters are the short, blunt-pointed cystidioles, which have cup-shaped wall thickenings at their bases. The hyphal tips at the dissepiment edges are not strongly differentiated; it could not be established whether the few crystals on their surfaces represent the Skeletocutis type (Keller 1979). In any case, the structure of the context suggests affinities with the Tyromyces-Skeletocutis generic complex (the genera understood according to David 1980, 1982). The finger-like, refractive hyphae closely resemble those of Tyromyces chioneus, but in that species they extend to the dissepiments, giving a stronger impression of a dimitic structure.

The hyphal system is not easily explained in this generic complex. In many species the solid hyphae arise as clampless side branches of the generative hyphae, and cannot properly be called skeletals (or binding hyphae, if strongly branched). In practice, however, the origin of such solid hyphae can be ascertained only after considerable toil, and the species are generally regarded as dimitic if unbranched and solid hyphae are found beside the thin-walled generative hyphae. Ryvarden and Gilbertson (1984) reported the present species as dimitic and for this reason (and because of the small spores) included it in the genus Antrodiella, while Ginns (1984) transferred it and the other species of Antrodiella to Flaviporus, when merging the two genera. I consider these transfers inadvisable, in view of the great differences in the microscopical structures. The fingerlike, solid hyphae in the context of $T$. canadensis have little in common with the slender skeletals of Antrodiella or Flaviporus, which form a dominant element throughout the fruit bodies. Small spores, very similar to those of $T$. canadensis are found, for example, in Skeletocutis jelićii Tortić \& David (David 1982, Kotiranta 1984). I prefer Tyromyces (to Skeletocutis) mainly because of the pileate habit, context microstructure and evident lack of encrustations, even though $T$. canadensis shows a variable positive metachromatic reaction. If this decision is correct, David (1980) and Jülich (1984) have overemphasized the $C R B$ reaction in the delimitation of the genus Tyromyces.

My material is, however, too scanty for certain determination of the most suitable genus. I have no field experience of the species. The Finnish specimen of $T$. canadensis was collected from an extensively decayed log, and the type of rot is not quite clear. If the species is really a Tyromyces (sensu David 1980), then it should produce white-rot and Lowe (1975) considered it to do so. Martin and Gilbertson (1978) report white-rot; Overholts (1953) does not define the decay.

$T$. canadensis is a fungus of coniferous trees. Most American authors leave the host tree species undefined, but Martin and Gilbertson (1978) mention Picea glauca. The present collection may be the first from the tree genus Pinus.

The American records come from the northern states of the U.S.A. (Idaho, Minnesota, Montana,
New York, Oregon and Washington) and from Canada (Ontario). The new find from northern Finland comes from a transitional area between the Northern boreal and Middle boreal zones. All this gives the impression that $T$. canadensis is northern in its general distribution.

\section{Nomenclatural notes}

The species was first described as Polyporus canadensis by Overholts (1941), but the name remained invalid as it lacked a Latin description. Lowe (1975:45) supplied the Latin description, but did so in a way that left its validity in doubt. The Latin diagnosis is presented in a footnote: 'Polyporus canadensis Overholts sp.nov. Pileo imbricato-sessili...' In his English text proper, Lowe $(1975: 44)$ makes the combination 'Tyromyces canadensis (Overh.) Lowe', referring to Pol. canadensis Overh., Mycologia 33:97, 1941, as the basionym, and to the footnote with the Latin description.

Ryvarden and Gilbertson (1984) consider both $P$. canadensis and $T$. canadensis as published by Lowe (1975) to be invalid, regarding them as alternative names and thus invalidly published according to Art. 34.4 in the Code ('When ... different names ... are proposed simultaneously for the same taxon by the same author, none of them is validly published'). Consequently they described the species anew, as Antrodiella overholtsii.

I cannot accept this solution, and favour the use of the old name for the following reasons.

If the spirit (rather than the letter) of the Code is considered, the matter is quite clear: there is no question of alternative names here. Lowe clearly indicates which genus (Tyromyces) he accepts himself. By the term 'alternative names' the Code means cases in which an author combines a name with two or more probable genera (or other ranks), in order to be sure that whichever of them turns out to be right, one of his combinations will remain. But for formal reasons also the old epithet should be maintained.

The name 'Polyporus canadensis Overholts' (Lowe 1975: 45, footnote) was actually not accepted by Lowe, this being the reason why he tried to make the new combination Tyromyces canadensis. Thus it is not an alternative name, but must be interpreted as a nomen invalidum: it is in the position of a synonym in the paper by Lowe, remaining invalid according to Art. 34:1(a) and (d).

For the name 'Tyromyces canadensis (Overh.) Lowe', Lowe (1975: 44) cites Polyporus canadensis Overh. 1941 (a nomen inval.) as a basionym, but the citation includes a reference to the footnote (Lowe 1975: 45, Latin description). This in fact means that Lowe (1975: 44) validly published a new species, which may be cited either as Tyromyces canadensis Lowe, or, using Rec. 46E.1 mechanically (as is normal in mycology), Tyromyces canadensis Overh. ex Lowe 1975.

For Tyromyces canadensis Overh. in Lowe to be acceptable, Rec. 46.1 requires that Overholts'supplied the description'. However, as Overholts had died in 

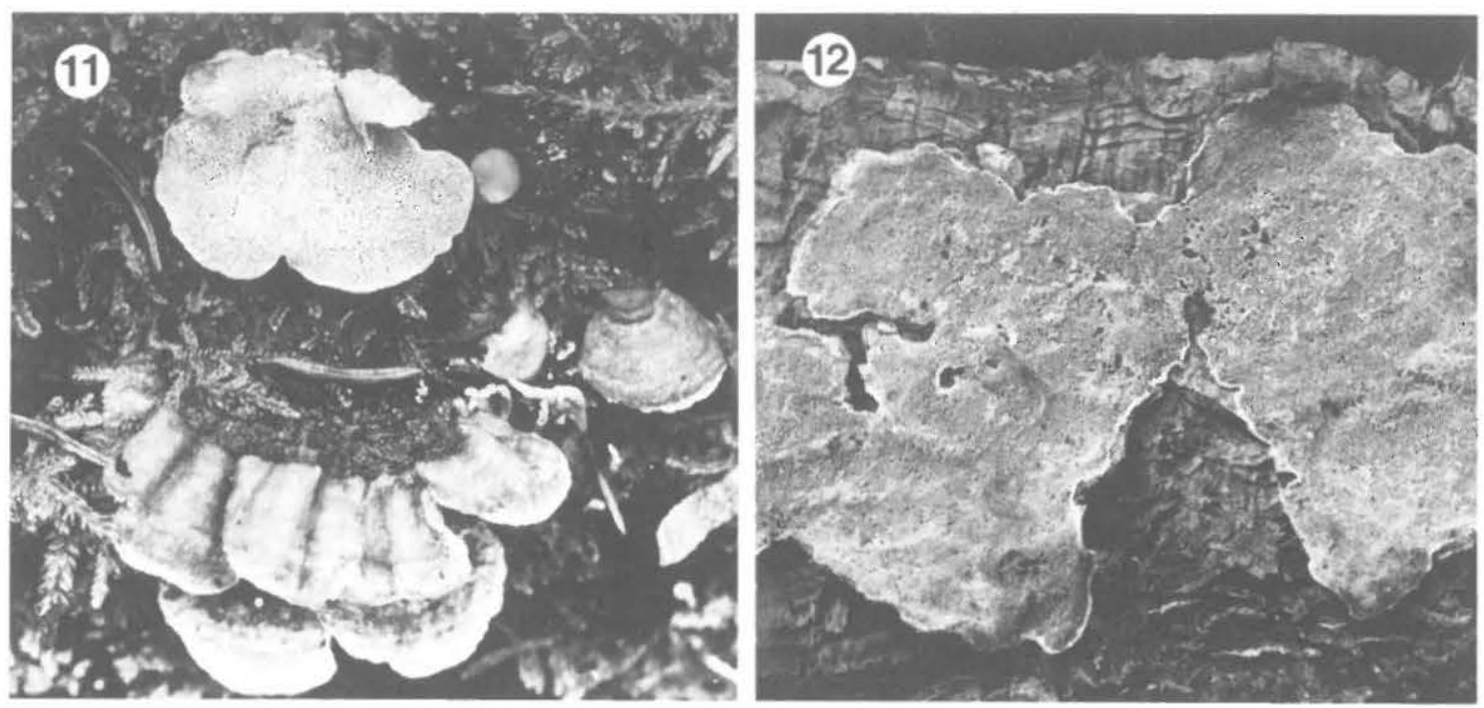

Figs. 11-12. Skeletocutis carneogriesea. -11 : Fresh, pileate fruit bodies, $\times 1$ 1.9. The largest one emerges from dead fruit body of Trichaptum abietinum (Niemelä 1730, T.N.). - 12: Dry, resupinate fruit body on spruce bark. Note the darkened pores and lighter sterile margin. $\times 1.6$ (Niemelä 1734, T.N.).

1946 and was known to neglect the Latin descriptions in his works, it is very unlikely that he supplied the validating Latin description, and it was Lowe who made it. Since the latter ascribed the epithet $P$. canadensis to Overholts, the citation Overh. ex Lowe is correct.

A somewhat deviating interpretation was expressed in the Index of Fungi (Kirk 1985). In it, the abovecited Latin description was accepted as validly published by Overholts, and the combination in Tyromyces would then be ' $T$. canadensis (Overh.) Lowe'. So this interpretation would also result in retention of the specific name given by Overholts.

Essentially the same confusion has just occurred in Fomes occidentalis Overh. (Lombard et al. 1972, Ginns 1984). These are excellent examples of the not infrequent situation in which the Code creates confusion, instead of helping to dissipate it. The above-mentioned taxa themselves have been clear and well understood all the time.

The Finnish collection of $T$. canadensis was made by the late Prof. Viljo Kujala (cf. Niemelä 1978b), who suspected it to represent an undescribed species. He refrained from describing it, merely using a provisional name in the herbarium labels.

My thanks are due to Mr. Heikki Kotiranta, M.Sc., for bringing the present material to my attention, and to Prof. J.L. Lowe (Syracuse, N.Y) and Prof. J.Ax. Nannfeldt (Uppsala) for sending me reference specimens. I am especially grateful to Prof. Teuvo Ahti and Dr. Pekka Isoviita (both from Helsinki) for several lengthy discussions on the troublesome nomenclature: the above conclusion is in accordance with their proposal.

\section{Specimens examined}

Finland. Pohjois-Pohjanmaa: Rovaniemi, Pisavaara National Park, Pinus sylvestris, 19.VIII.1957 Kujala (HFR 4260-4261, H, UPS). Canada. Ontario: Ottawa, Picea, 16.IX.1933 Groves (Herb. Overholts 16860, PAC, holotype). U.S.A. New York: Newcomb, coniferous wood, 20.VIII.1947 Lowe (SYRF), 31.VIII.1948 Lowe 3355 (H), Lowe 3361 (SYRF). Warrensburg, coniferous wood, 10.IX.1934 Smith 762 (SYRF), Lowe 2357 (SYRF).

\section{Notes on Skeletocutis \\ Skeletocutis carneogrisea}

New to Finland. S. carneogrisea David (1982) was described from France, and specimens were mentioned from Switzerland, Sweden and Canada. Jahn (1983) reported over 10 localities in western Germany. The species is close to $S$. amorpha (Fr.) Kotl. \& Pouz., but differs in having pale greyish-red pores instead of bright orange, in the dirty light grey cap, commoner skeletal hyphae in the dissepimental edges, and narrower and more curved spores. The hyphae in the upper tube trama are subparallel in $S$. carneogrisea vs. intermixed in S. amorpha (Jahn 1983). The pore area, which is pale when fresh, darkens on drying, leaving the narrow sterile margin characteristically lighter (Fig. 12). The orange pores of $S$. amorpha rapidly turn coral red under a drop of $\mathrm{KOH}$, but this reaction was not noted in $S$. carneogrisea. David describes the species as predominantly resupinate, but the Finnish collections show well-developed, thin caps, too (Fig. 11). They are ear-shaped, like those of $S$. amorpha, and $S$. carneogrisea clearly belongs to Skeletocutis in the strict sense. 
Though its specific status was confirmed so late, $S$. carneogrisea was not unknown to mycologists earlier. In particular, the notes on $S$. amorpha $\mathrm{f}$. mollusca in various publications (Bourdot \& Galzin 1928, Domański 1963, Bondarceva 1964, Domański et al. 1973) seem to refer to it. The type of Bjerkandera mollusca Karst. is not this taxon, as shown by David (1982); the host Pinus sylvestris (Karsten 1887) also excludes $S$. carneogrisea.

David mentions the curious tendency of this species to grow together with Trichaptum abietinum (Pers.: Fr.) Ryv. and T. fuscoviolaceum (Ehrenb.: Fr.) Ryv.: this feature was noted earlier by Domański et al. (1973) and, especially, by Göpfert (1977), who published a thorough description of the ecology. Further, the Finnish specimens were found in association with dead fruit bodies of $T$. abietinum. I have seen an abundant set of specimens from the northern U.S.S.R. (coll. Parmasto), and they strikingly often revealed this succession, too.

$S$. amorpha favours Pinus as the host genus, while $S$. carneogrisea occurs almost exclusively on Picea and (in Central Europe) Abies. S. amorpha prefers man-made stumps of pine, while $S$. carneogrisea occurs on fallen spruce trunks.

The Finnish finds of $S$. carneogrisea date from late autumn, and the sites had already experienced periods of frost; Göpfert (1977) mentions its late occurrence, too. It seems that $S$. carneogrisea is one of the latest fungi in the season, and that it has been neglected because of this, and beause it resembles deteriorating $S$. amorpha that has already lost its bright colours. In the microscope these late collections prove to be in perfect condition and fertile.

I have not attempted to check the herbarium material of $S$. amorpha for misidentified collections of this species.

I am grateful to Mme Alix David (Lyon), who forwarded me reference material. Prof. Erast Parmasto (Tartu) sent me an ample set of collections from the U.S.S.R.; I also had a long discussion with him on this taxon during the International Symposium on Aphyllophorales, Eisenstadt (Austria), 1982.

Finland. Uusimaa: Vantaa, Picea abies, 14.X.1979 Niemelä 1730 \& Kotiranta (T.N.), 17.X.1979 Niemelä 1734 \& Kotiranta (T.N.).

\section{Skeletocutis odora}

Polyporus odorus Peck, New York State Mus. Ann. Rep. 38: 92, 1885, nom.illegit. (homonym of Polyporus odorus Sommerf., Suppl. Florae Lapponicae: 275, 1826). Poria odora Saccardo, Syll. Fung. 6: 294, 1888. Holotype: 'Polyporus odorus Pk., [U.S.A., New York,] Osceola, $\mathrm{Cha}^{\mathrm{S}} \mathrm{H}$. Peck' (NYS, examined). - Skeletocutis odora (Sacc.) Ginns, Mycotaxon 21: 332, 1984.

Poria tschulymica Pilát, Bull. Soc. Mycol. France 48: 35, 1932. Holotype: 'Poria tschulymica Pilát, [U.S.S.R.,] Sibiria, distr. Tomsk, ad fl. Tschulym, Populus tremula, IX.1931 Krawtzew' (PRM 605233, examined). - Incrustoporia tschulymica (Pilát) Dom., Acta Soc. Bot. Poloniae 32: 737, 1963. - Skeletocutis tschulymica (Pilát) Keller, Persoonia 10: 353,1979

The type of $S$. odora was described by Lowe (1966, as Poria odora), and only a few additional notes are needed. Most measurements of type give 6-9 pores per $\mathrm{mm}$. The tubes tend to become compressed and split into $v$-shaped fissures on drying, and in dry condition are resinous-waxy and pale toffee-coloured, contrasting with the lighter (cream-coloured) subiculum. The subiculum is 'pseudo-dimitic' (term of David 1982), composed of a loose tissue of rather thin-walled generative hyphae, which are branched and with clamp connections, and refractive flexuose hyphae, which resemble the skeletals but have occasional clamp connections, too. A gelatinous layer of tightly agglutinated hyphae is found in many places in the upper subiculum, adjacent to the substrate. The dissepimental trama is composed of thin-walled, clamped generative hyphae, packed tightly in a subparallel fashion; occasional refractive hyphae also occur. Abundant encrusted hyphae line the dissepiment edges: they are twisted and the crystals are of the Skeletocutis type (Keller 1979). The hymenium consists of small, bottle-shaped, inconspicuous cystidioles; the spores measure $4-5$ $\times 0.9-1.2 \mu \mathrm{m}$.

The type of $S$. odora differs from the type of $P$. tschulymica in having smaller pores (the latter ca. 45 per $\mathrm{mm}$ ) and slightly more resinous tubes. However, the species is known to vary remarkably in pore size, depending on the vigour of growth, the age and the position of the substrate. Gilbertson (1974), who has studied more North American material of $S$. odora, reports that the pores number $4-6$ per $\mathrm{mm}$. In the microscope the types were found to be similar, corresponding with the numerous collections of the species in Finland. The epithet odora is good: in fresh condition the fruit bodies have a strong odour, described as garlic (Gilbertson 1974), nauseous (David 1982) or resembling the defensive smell of some herbicolous bugs (Hemiptera, Geocorisae: Pentatomidae). In North America the species is known from gymnosperms, while the type of $P$. tschulymica is from Populus tremula. Coniferous trees (mainly Picea abies) and aspen are the hosts of the species in Europe as well (David 1982).

Pol. odorus Peck cannot serve as the basionym of the species because it is a later homonym of Pol. odorus Sommerfelt. The latter species is now better known as Haploporus odorus (Sommerf.) Bond. \& Sing. (Niemelä 1971). The first available basionym is Poria odora Sacc. ('Poria odora (Peck) Sacc.'), an unintentional nomen novum. This author change, of course, does not alter the typification, nor does it make the combination of Ginns (1984) invalid: the wrong author's citation can be regarded as a bibliographic error only.

Ginns (1984) noted that Pol. odorus belongs to the genus Skeletocutis, but failed to recognize its synonymy with $S$. tschulymica, which has a wide distribution in Eurasia. The idea that they are conspecific was suggested to me by Dr. Zdeněk Pouzar (Praha) during my visit to Czechoslovakia in 1973. I am grateful to him for permission to publish the synonymy. I also thank Dr. Harri Harmaja (Helsinki) for his note on the homonymy of Peck's epithet. 


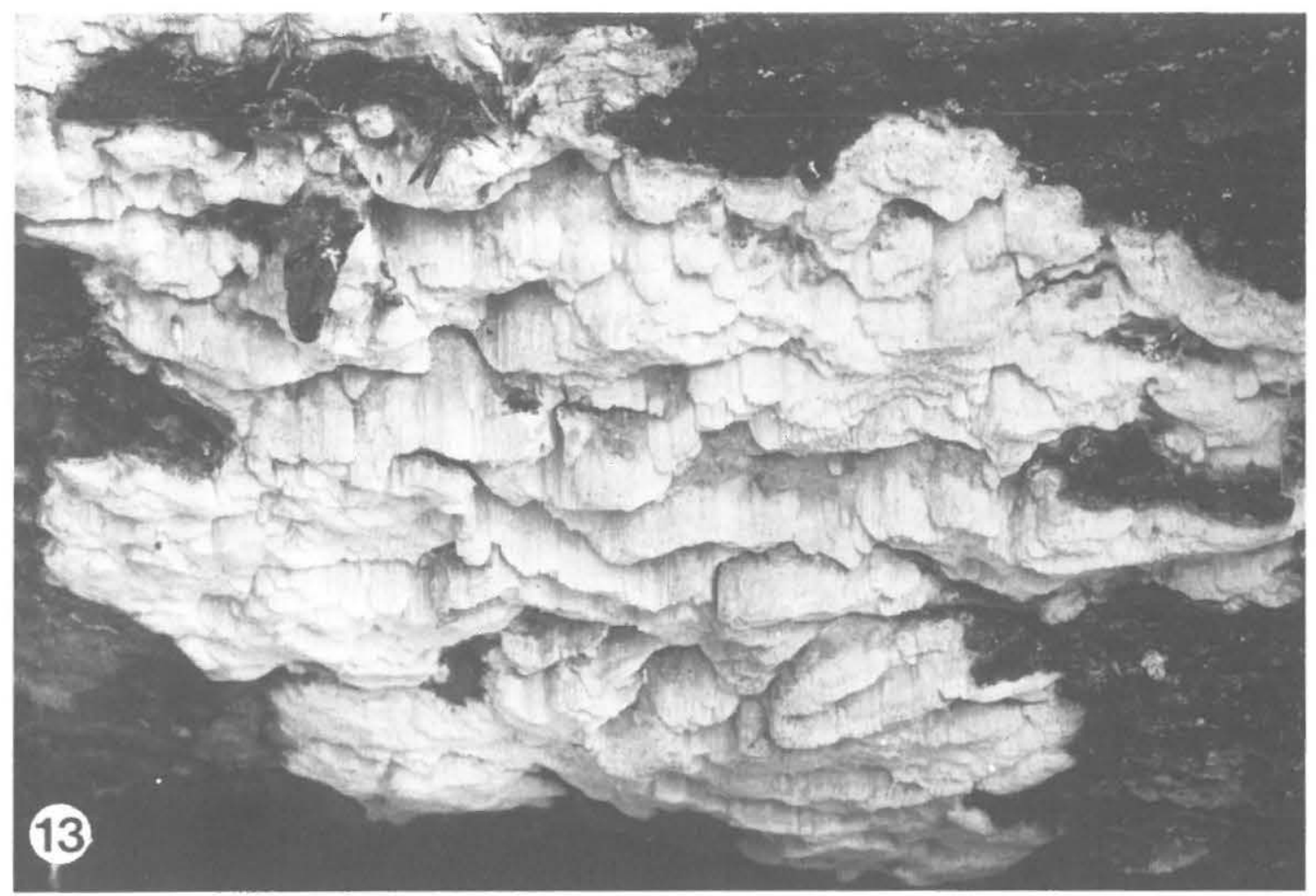

Fig. 13. Skeletocutis odora, photographed in situ, $\times 0.8$ (Niemelä $2125, \mathrm{H})$.

\section{Notes on Antrodia}

Antrodia pulvinascens (Pilát) Niemelä, n.comb.

Poria pulvinascens Pilát, Atlas des Champignons de l'Europe 3: 451, 1941 (nom.inval.); Sborn. Nár. Mus. Praha 9B(2): 106, 1953. Type: 'Poria pulvinascens Pilát, [Sweden,] Upland, Bondkyrka, Vårdsätra, Salix, 16.X.1936 Seth Lundell' (holotype PRM 756485, isotype UPS 1451, both examined). Antrodia plicata Niemelä, Karstenia 18: 44, 1978. Holotype: Finland, Satakunta, Noormarkku, Populus tremula, 27.VI.1939 Laurila $550(\mathrm{H}$, isotype $\mathrm{O})$.

The microscopy, morphology and ecology of the species were treated in detail by Niemelä (1978a) under the name $A$. plicata. Now it has turned out that $P$. pulvinascens is an older name for the taxon. Pilát (1936-1942) first published descriptions in French and Czech only: these are invalid, since the date of publication is 25 November 1941, and the Code necessitates Latin descriptions for new names of taxa from the beginning of 1935. A Latin description was provided afterwards (Pilát 1953). Only the Swedish specimen of Seth Lundell was mentioned in these papers, so that the typification does not cause any difficulties. Pilát mentioned the specimen in Praha (PRM), which must therefore serve as the holotype; the fragments in Stockholm (S) are clearly from the same collection and I regard them as isotype material.

Different opinions have been expressed on the identity of Poria pulvinascens. Domański (1964) considered the type to represent a young stage of Diplomitoporus crustulinus (Bres.) Dom. (Poria crustulina). Many details contradict this: the spore shapes and basidial types are different, $D$. crustulinus produces soft-fibrous white-rot and grows on conifers. Ryvarden (1970), too, disagreed with Domański's conclusion and ascribed $P$. pulvinascens to Ceriporiopsis aneirina (Sommerf.) Dom. (Poria aneirina). He listed several characters which connect the type material with $C$. aneirina, and it is true that it has much in common with that species. Ryvarden dealt with the dimiticity of $P$. pulvinascens by observing that $C$. aneirina (s.lat.) often has thickwalled hyphae, thus appearing to be dimitic.

In theory there should be no difficulty in separating the species of Antrodia from Ceriporiopsis. The Antrodia species are dimitic, have narrow (mostly ellipsoid-fusiform) spores and produce brown-rot. The Ceriporiopsis species are monomitic, with rather obtuse-ended spores and white-rot. In practice the separation of young specimens of $A$. pulvinascens from some taxa of Ceriporiopsis (in particular C. resinascens (Rom.) Dom.) appears surprisingly diffucult, especially if the character of rot cannot be identified. The type specimen of $A$. pulvinascens is really 


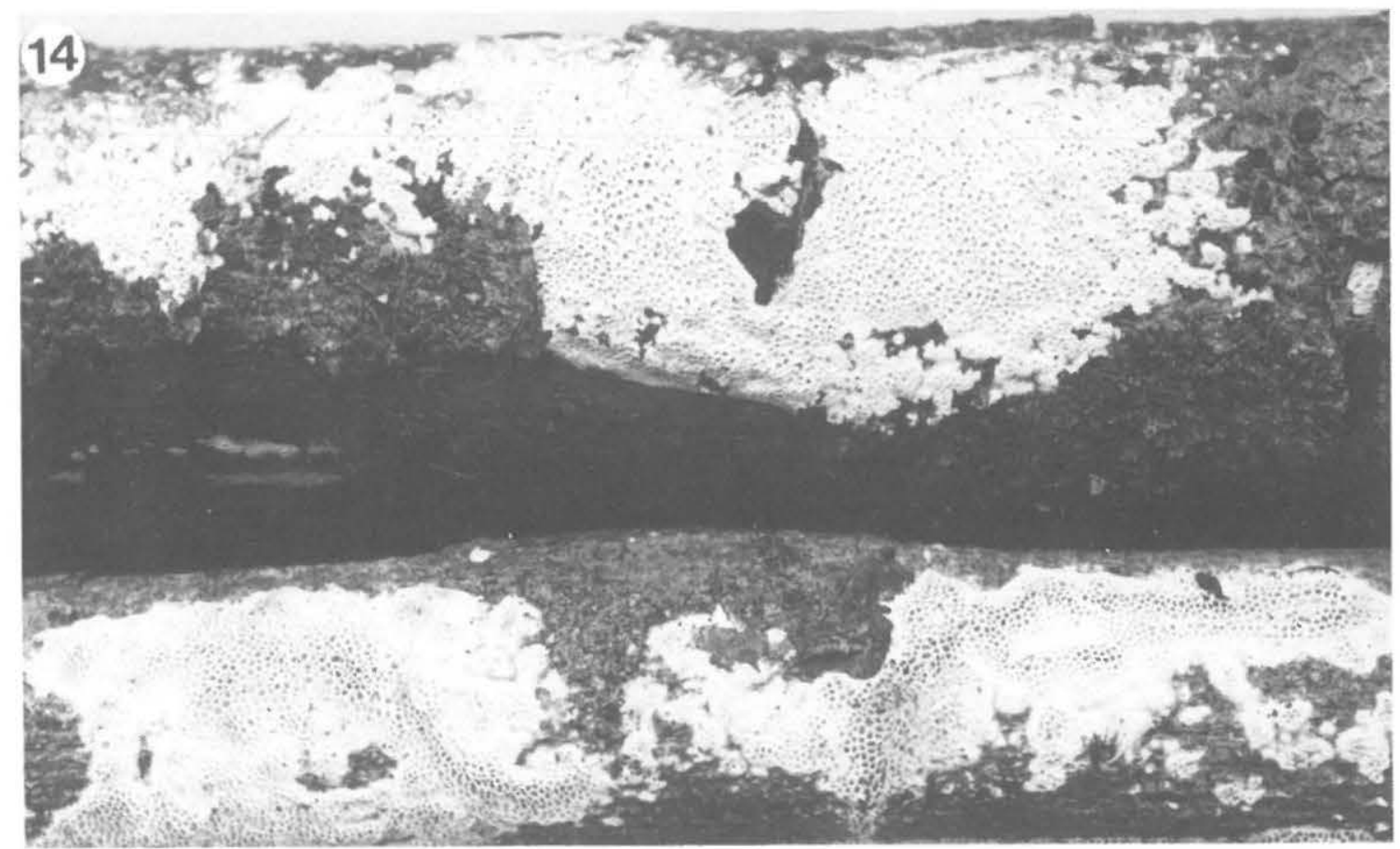

Fig. 14. Antrodia macra, fresh fruit bodies, $\times 1.5$ (Saarenoksa 6384, H).

troublesome in this respect: the fruit bodies are young (second year's growth visible in some areas only) and substerile, and the rot is very weakly developed.

C. aneirina (in the sense of the type specimen; some Finnish collections also studied, cf. Domański 1972: 31) has thin-walled hyphae throughout and is fairly easily separated from Antrodia. C. resinascens (type and numerous Finnish and Czech collections examined), on the other hand, has abundant thickwalled to solid hyphae in the subiculum, which thus appears to have a dimitic structure. These sclerified hyphae have very few branches and clamp connections, which makes their separation from true skeletals harder still. In Ceriporiopsis the thick-walled hyphae are restricted to the subiculum, while in Antrodia the refractive skeletals extend all the way down the dissepimental trama. I regard this as the best difference for telling young $A$. pulvinascens from $C$. resinascens: the spores are about the same size and very variable in the latter species. The confusion is aggravated by the fact that the name $C$. resinascens seems to comprise several taxa.

The known distribution of $A$. pulvinascens in Fennoscandia is mapped in Fig. 8. The Swedish records are according to the specimens preserved in UPS; earlier Fennoscandian localities were listed by Niemelä (1978a) and Kotiranta and Niemelä (1981).

I thank Dr. Svengunnar Ryman, who helped me in my work during a visit to Uppsala. Mr. Heikki Kotiranta placed an unpublished Finnish record at my disposal.
Antrodia macra (Sommerf.) Niemelä, n.comb.

Polyporus macer Sommerfelt, Suppl. Florae Lapponicae: 279, 1826. Holotypus: 'Polyporus macer Sommf., vulgaris Fr., [Norway, Nordland,] Saltdalen, in ligno populino putrido, $10 / 21$ [=October 1821, handwriting of Sommerfelt]' (herb. Sommerfelt, O, examined).

Trametes salicina Bresadola in Egeland, Nyt Mag. Naturvidensk. 52: 166, 1914. Lectotypus: 'Trametes salicina Bres., [Norway,] Ullern, på Salix, 27.X.1912 J. Egeland' (O). - Antrodia salicina (Bres.) Niemelä, Karstenia 18: 48, 1978.

Lowe (1966) reduced Pol. macer to synonymy with Poria (Ceriporiopsis) aneirina, this treatment being followed by Donk (1974) and Jülich (1984).

The type consists of fragments of resupinate fruit bodies, which are cream to cork-coloured, annual, thin, and with a thinning margin. The pores are angular, $2-3$ per $\mathrm{mm}$, with scattered wider pores, 1 per mm, formed by a fusion of two or more smaller ones. The fungus has produced distinct brown-rot on adjacent wood. The structure is dimitic throughout, with thin-walled and clamped generative hyphae and refractive skeletals, both ca. $3-4 \mu \mathrm{m}$ in diam. Unripe basidia and basidioles are $22-27$ $\times 7-9 \mu \mathrm{m}$, with vesicular-swollen apices and slender bases; some of the basidioles have sharp or even hyphoid apices, and can then be taken for cystidioles. No thick-walled elements occur in the hymenium. Spores were extremely rare, ca. $9 \times 3.5 \mu \mathrm{m}$.

The dimitic structure and brown-rot rule out the possibility of Ceriporiopsis: the type is an indisputable Antrodia. Its pores are much too shallow and 
wide for A. pulvinascens, and the spores too long. Repeated comparisons between it and specimens of (what I regard as) typical $A$. salicina led me to the conclusion that they represent the same species. The differences between this taxon and the group of $A$. serpens (Fr.: Fr.) Karst., A. albida (Fr.: Fr.) Donk and $A$. heteromorpha (Fr.: Fr.) Donk were discussed by Domański (1972).

My best thanks to Dr. Gro Gulden (Oslo) for arranging the loans and for interpreting the script of Sommerfelt.

\section{References}

Baxter, D. 1939 ('1938'): Some resupinate polypores from the region of the Great Lakes 10. - Pap. Michigan Acad. Sci. Arts Lett. 24: 167-188.

- 1949 ('1947'): Some resupinate polypores from the region of the Great Lakes 19. - Pap. Michigan Acad. Sci. Arts Lett. 33: 9-30.

Bondarcev, A. 1953: Trutovye griby evropejskoj časti SSSR i Kavkaza. - 1106 pp. Moskva \& Leningrad.

Bondarceva, M. 1964: Novye dlya Leningradskoj oblasti vidy i formy Polyporaceae i Aporpiaceae. - Novosti Sist. Nižs. Rast. 1964: 186-195.

Bourdot, H. \& Galzin, A. 1928: Hyménomycètes de France. -761 pp. Sceaux.

Corner, E. 1953: The construction of polypores 1. Phytomorphology 3: 152-167.

David, A. 1972: Comportement nucléaire des représentants du genre Gloeoporus Mont.: G. conchoides Mont., G. dichrous (Fr.) Bres. et G. pannocinctus (Rom.) J. Erikss. récolté pour la première fois en France. - Bull. Soc. Mycol. France 88: 209-213.

- 1980: Etude du genre Tyromyces sensu lato: Répartition dans les genres Leptoporus, Spongiporus et Tyromyces sensu stricto. - Bull. Soc. Linn. Lyon 49: 6-56.

- 1982: Etude monographique du genre Skeletocutis (Polyporaceae). - Naturaliste Canadien 109: 235-272.

David, A. \& Keller, J. 1984: Une nouvelle espèce de Skeletocutis (Polyporaceae) recoltée en Suisse. Mycologia Helvetica 1: 157-167.

Domański, S. 1963: Fungi lignicoli in regione Masury in Polonia septentrionali annis 1956-1961 collecti. Monogr. Bot. 15: 295-323.

- 1964: Révision de certaines espèces de champignons de la famille Polyporaceae. - Acta Soc. Bot. Poloniae 33: $167-178$.

- 1966: Studium porównawcze nad grzybami polyporoidalnymi: Polyporus dichrous Fr. i Polyporus pannocinctus Romell, - Acta Mycol. 2: 151-168.

- 969: Grzyby zasiedlajace drewno w Puszczy Białowieskiej 10. Fibuloporia subvermispora (Pilát) Domań., comb.nov. i jej rozpoznanie. - Acta Soc. Bot. Poloniae 38: 453-464.

- 1970: Grzyby zasiedlajace drewnow Puzczy Białowieskiej 15. Polyporus dichrous Fr. i Polyporus pannocinctus Romell w kulturze. - Acta Soc. Bot. Poloniae 39: 531 538

- 1972: Fungi: Polyporaceae 1, Mucronoporaceae 1. 235 pp. Warsaw.

Domański, S., Orlos, H. \& Skirgiello, A. 1973: Fungi: Polyporaceae 2, Mucronoporaceae 2, etc. - 331 pp. Warsaw.

Donk, M. 1974: Check-list of European polypores. - 469 pp. Amsterdam \& London.

Eriksson, J. 1958: Studies in the Heterobasidiomycetes and Homobasidiomycetes-Aphyllophorales of Muddus National Park in North Sweden. - Symb. Bot. Upsalienses 16(1): 1-172.

Fischer, W. 1979: Climacodon septentrionalis und Gloeoporus pannocinctus in der DDR. - Boletus 3: $33-35$.
Gilbertson, R. 1974: Fungi that decay Ponderosa pine. 197 pp. Tucson, AZ.

Gilbertson, R., Burdsall, H. \& Larsen, M. 1975: Notes on wood-rotting Hymenomycetes in New Mexico. Southwest. Naturalist 19: 347-360.

Ginns, J. 1979: Henningsia (Polyporaceae) and a description of the type species. - Mycologia 71: 305-309.

- 1984: New names, new combinations and new synonymy in the Corticiaceae, Hymenochaetaceae and Polyporaceae. - Mycotaxon 21: 325-333.

Göpfert, H. 1977: Eine besondere Form des Knorpelporlings. - Schweiz. Z. Pilzkunde 55: 162-163.

Gordienko, P. 1979: Vlianie sostoania substrata na rasselenie derevorazrušayuših gribov. - Mikol. Fitopatol. 13: $421-428$.

Hallenberg, N. 1979: Wood fungi (Polyporaceae, Ganodermataceae, Hymenochaetaceae, Cyphellaceae, Clavariaceae, Auriculariaceae, Tremellaceae, Dacrymycetaceae) in Iran 2. - Iranian J. Plant Pathol. 15: $11-31$.

Hjortstam, K. \& Ryvarden, L. 1982: Aphyllophorales from northern Thailand. - Nordic J. Bot. 2: 273-281.

Ingelög, T., Thor, G. \& Gustafsson, L. (eds.) 1984: Floravård i skogsbruket 2 , artdel. -407 pp. Jönköping.

Jahn, H. 1983: Skeletocutis carneogrisea David, ein Doppelgänger von S. amorpha - Funde in Deutschland. - Westfäl. Pilzbriefe 10-11:271-277.

Järva, L. \& Parmasto, E. 1980: Eesti seente koondnimestik. - Scripta Mycol. 7: 1-331.

Jülich, W. 1984: Die Nichtblätterpilze, Gallertpilze und Bauchpilze (Aphyllophorales, Heterobasidiomycetes, Gastromycetes). - In: Gams, H., Kleine Kryptogamenflora 2b(1): Basidiomyceten 1. 626 pp. Stuttgart \& New York.

Karsten, P. 1887: Fungi novi vel minus bene cogniti Fenniae et Galliae descripsit. - Rev. Mycol. 9: 9-11.

Keller, J. 1979: Ultrastructure des hyphes incrustées dans le genre Skeletocutis. - Persoonia 10: 347-355.

Kirk, P. (ed.) 1985: Index of Fungi 5: 329-376.

Komarova, E. 1964: Opredelitel' trutovyh gribov Belorussii. $-343 \mathrm{pp}$. Minsk.

Kotiranta, H. 1984: Skeletocutis jelicii: a new member of the Finnish polypore flora. - Karstenia 24: 73-76.

Kotiranta, H. \& Niemelä, T. 1981: Composition of the polypore communities of four forest areas in southern Central Finland. - Karstenia 21: 31-48.

Kotlaba, S. 1984: Zemépisné rozšî́rení a ekologie chorosů (Polyporales s.l.) v Ceskoslovensku. - 194 pp. Praha.

Kotlaba, S. \& Pouzar, Z. 1964: Studie o bèlochoroši nazelenalém, . Tyromyces pannocinctus (Romell) comb.nov. - Ceská Mykologie 18: 65-76.

Lindsey, J. \& Gilbertson, R. 1978: Basidiomycetes that decay aspen in North America. - Biblioth. Mycol. 63: 1106.

Lombard, F., Davidson, R. \& Gilbertson, R. 1972: Studies of two species of Phellinus in western North America. - Mycopath. Mycol. Appl. 46: 351-356.

Lowe, J. 1956: Type studies of the polypores described by Karsten. - Mycologia 48: 99-125

- 1966: Polyporaceae of North America. The genus Poria. - State Univ. Coll. For. Syracuse Univ., Techn. Publ. 90: $1-183$.

- 1975: Polyporaceae of North America. The genus Tyromyces. - Mycotaxon 2: 1-82.

Martin, K. \& Gilbertson, R. 1978: Synopsis of wood-rotting fungi on spruce in North America 2. - Mycotaxon 7: $337-356$

Melik-Haćatryan, D. \& Martirosyan, S. 1971: Mikoflora Armyanskoj SSR 2, gasteromičety i afilloforovye griby. - 382 pp. Erevan.

Nakasone, K. 1981: Cultural studies on Poria cinerascens, P. rivulosa and P. subvermispora (Aphyllophorales, Basidiomycotina). - Mycotaxon 13: 105-111.

Niemelä, T. 1971: On Fennoscandian polypores 1. Haploporus odorus (Sommerf.) Bond. \& Sing. - Ann. Bot. Fennici 8: 237-244. 
- 1978a: On Fennoscandian polypores 6. Antrodia plicata n.sp. - Karstenia 18: 43-48.

- 1978b: The occurrence of some rare pore fungi in Finland. - Ann. Bot. Fennici 15: 1-6.

- 1985: Mycoflora of Poste-de-la-Baleine, northern Québec. Polypores and the Hymenochaetales. Naturaliste Canadien 112 (in press).

Overholts, L. 1941: New species of Polyporaceae. Mycologia 33: 90-102.

- 1953: The Polyporaceae of the United States, Alaska, and Canada. - 466 pp. Ann Arbor.

Parmasto, E. 1957: Mycotheca Estonica 1: 1-25. - 22 pp. Tartu.

- 1959: Trytovye griby Estonskoj SSR. - Trudy Bot. Inst. Komar. AN SSR (Ser. 2, Spor. Rast.) 12: 213-273.

- 1963a: K mikologičeskoj flore Komi ASSR. - Tartu Riikl. Ülik. Toim. 136 (Bot.-alased Tööd 6): 103-129.

- 1963b: K flore gribov poluostrova Kamčatki. - Issl. Prirody Dal'nego Vostoka 1: 221-289.

- 1983: Leucophellinus mollissimus - tropičeskij trutovyj grib na Dal'nem Vostoke SSSR. - Eesti NSV Tead. Akad. Toim. (Biol.) 32: 264-272.

Pilát, A. 1936-1942: Polyporaceae. - In: Kavina, C. \& Pilát, A. (eds.), Atlas des champignons de l'Europe 3: $1-624$, 374 pls. Praha.

- 1940: Species novae boreali-americanae generis Poria. - Stud. Bot. Cechica 3: 1-4.

- 1953: Hymenomycetes novi vel minus cogniti Cechoslovakiae 2. - Sborn. Nár. Mus. Praha 9B(2): $1-109$.

Ryman, S. 1984: Gloeoporus pannocinctus (Romell) J. Erikss. - In: Ingelög, T., Thor, G. \& Gustafsson, L. (eds.), Floravård i skogsbruket 2, artdel: 350 . Jönköping.

Ryvarden, L. 1970: New or interesting records of Norwegian polypores 2. - Nytt Mag. Bot. 17: 163-168.

- 1971: Studies in the Aphyllophorales of Finnmark, northern Norway. - Rep. Kevo Subarctic Res. Sta. 8: $148-154$.
- 1973: Some genera of resupinate polypores with a note on Aleurodiscus norvegicus nov.sp. - Norwegian J. Bot. 20: 7-11.

- 1976: The Polyporaceae of North Europe 1. Albatrellus to Incrustoporia. $-214 \mathrm{pp}$. Oslo.

Ryvarden, L. \& Gilbertson, R. 1984: Type studies in the Polyporaceae 15 , species described by L.O. Overholts, either alone or with J.L. Lowe. - Mycotaxon 19: 137144.

Ryvarden, L. \& Johansen, I. 1980: A preliminary polypore flora of East Africa. - $636 \mathrm{pp}$. Oslo.

Singer, R. 1975: The Agaricales in modern taxonomy. 3rd edition. - 912 pp. Vaduz.

Stalpers, J. 1978: Identification of wood-inhabiting Aphyllophorales in pure culture. - Stud. Mycol. CBS, Baarn 16: 1-248.

Strid, A. 1975: Wood-inhabiting fungi of alder forests in North-Central Scandinavia 1. Aphyllophorales (Basidiomycetes), taxonomy, ecology and distribution. - Wahlenbergia 1: 1-237.

Telleria, M. 1980: Contribución al estudio de los Aphyllophorales españoles. - Biblioth. Mycol. 74: 1464.

Tortić, M. 1976: Some experiences with the use of cresyl blue in the determination of polypores. - Kew Bull. 31: $611-616$

- 1984: Distribution of polypores in Yugoslavia 1. Amylocystis, Anomoporia, Aurantioporus, Fibuloporia. - Ácta Bot. Croat. 43: 65-72.

Tortić, M. \& Kotlaba, F. 1976: A handful of polypores, rare or not previously published from Yugoslavia. - Acta Bot. Croat. 35: 217-231.

Ulvinen, T., Ohenoja, E., Ahti, T. \& Alanko, P. 1981: A checklist of the fungi (incl. lichens) of the Koillismaa (Kuusamo) biological province, NE Finland. - Oulanka Rep. 2: $1-64$.

Accepted for publication

on February 8, 1985 